\title{
Responses to Saving Commitments: Evidence from Mortgage Run-offs
}

\author{
Steffen Andersen, Philippe d’Astous, Jimmy Martínez-Correa and Stephen H. Shore. ${ }^{1}$
}

First draft: May 2017

This version: April 2018

\begin{abstract}
We study consumers' responses to removing a saving constraint. Mortgage run-offs predictably relax a saving constraint for borrowers whose mortgage committed them to save by paying down principal. Using the entire Danish population, we identify mortgages on track to run off between 1995 and 2014. We measure the effect of run-offs on earnings and the household balance sheet. We find that borrowers use 39 percent of previous mortgage payments to decrease labor income, and use 53 percent to pay down other debts. Borrowers run up non-mortgage debt prior to the run-off and this run-up stops once the mortgage is repaid.
\end{abstract}

1 Andersen: Department of Finance, Copenhagen Business School, Porcelaenshaven 16A, DK-2000 Frederiksberg, Denmark, email: san.fi@cbs.dk. d’Astous: Department of Finance, HEC Montréal, 3000 Chemin de la Côte-SainteCatherine, Montréal, Québec, H3T 2A7, Canada, email: philippe.dastous@hec.ca. Martínez-Correa: Department of Economics, Copenhagen Business School, Porcelaenshaven 16A, DK-2000, Frederiksberg, Denmark, email: ¡ima.eco@cbs.dk. Shore: Department of Risk Management and Insurance, Robinson College of Business, Georgia State University, 35 Broad Street, Atlanta, GA 30303, USA, email: sshore@gsu.edu. We thank the Pension Research Center (PeRCent) at the Copenhagen Business School and the Retirement and Savings Institute at HEC Montréal for financial support. We thank Rob Alessie (discussant), Ben Keys (discussant), Jeanne Lafortune (discussant), John Leahy, Alex Michaelides (discussant), Dan Silverman, and seminar participants at the CEPR European Conference on Household Finance 2017, the Colloquium on Financial Planning 2018, the EAFIT Behavioral Finance Workshop 2017, the Federal Reserve Bank of Atlanta Real Estate Finance Conference, Georgia State University, HEC Montréal, the Netspar International Pension Workshop 2018, the Semiannual PeRCent Meetings 2016 and 2017, and the Utah State Quantitative Society for Pensions and Savings Workshop 2017 for many useful comments, and Ann-Lea Falk Larsen for excellent and dedicated research assistance. 


\section{Introduction}

Compulsory saving schemes potentially force some households to save more, and spend less, than they would otherwise prefer. Employer and government pension programs are an example of such compulsory savings constraint. Similarly, for some individuals mortgages can act as a self-imposed saving commitment. Mortgage borrowers effectively save in housing equity by making principal payments to reduce their mortgage debt; to obtain favorable rates, borrowers typically choose mortgage contracts which commit them to a predetermined schedule of such payments.

Mortgage run-offs provide an ideal natural experiment to identify the consequences of relaxing a self-imposed saving commitment. Mortgages run off when borrowers complete their schedule of payments and bring their mortgages balance to zero without prepayment. After a run-off, borrowers are no longer forced to save by paying down their mortgages; they can allocate freed-up resources to saving elsewhere, spending more, or increasing leisure by working less. Because unconstrained borrowers can offset saving commitments by borrowing or saving less elsewhere prior to the run-off, savings commitments should only affect those for whom the mortgage contract constrains saving and consumption decisions.

Measuring the consumption and investment response to a mortgage run-off can be seen as a test of a variant of the Permanent Income Hypothesis, PIH henceforth (Modigliani and Brumberg, 1954; Friedman, 1957). The PIH implies that unconstrained, rational, forwardlooking, risk-averse individuals should not change their consumption in response to a predictable change in income. Individuals who anticipate that their income will increase in the future should draw down savings to increase consumption today, so that consumption will not increase when income does. A mortgage run-off has the same consumptionsmoothing prediction: rational, unconstrained borrowers should not change consumption after the run-off. This smoothing is achieved by borrowing or drawing down savings to make mortgage payments prior to the run-off. The theoretical prediction is that non-mortgage net wealth should fall leading up to the run-off as unconstrained borrowers offset mortgage principal payments and this wealth decumulation should stop after the run-off. As a result, net non-mortgage savings increases after the run-off. 
The empirical validity of the PIH has been tested in many different settings ${ }^{2}$ and the failure of the PIH is often attributed to a liquidity constraint which prevents individuals from borrowing to smooth consumption (Deaton, 1991; Carroll, 1997). The effect of a mortgage run-off on consumption, asset accumulation and other debt repayment should also vary with the financial position of the borrower. On one hand, the mortgage repayment schedule does not impose a constraint on the saving rate or consumption of individuals that choose to save elsewhere while paying down their mortgage, or can borrow using non-mortgage debt. These unconstrained individuals could save less or borrow elsewhere to offset the saving commitment imposed by the mortgage and they could always liquidate some of their savings to finance consumption if they wanted to increase it. On the other hand, individuals who do not wish to save as much as the mortgage contract requires must choose to either consume less or borrow elsewhere at higher rates. Individuals who chose to consume less in response to the mortgage's saving commitment would be expected to spend some of the resources freed up by the run-off, either on leisure (working less) or consumption. We present a theoretical framework formalizing these predictions in Section 2: reduced labor income postrun-off, particularly among those expected to be more constrained and increased saving and reduced non-mortgage debt post-run-off, particularly among those expected to be less constrained.

We investigate these predictions empirically by examining the evolution of earning and of the main components of households' balance sheet in the years before and after mortgage run-offs. The data used in our analysis include year-end information on the universe of the Danish population for nearly all assets and liabilities - including those in bank accounts, investments, credit cards, mortgages, and homes - as well as employment status, pension contributions and payouts, and labor income. This allows us to examine many margins of adjustments in response to relaxing a saving constraint.

We find that the final mortgage payments leads to two observable adjustments. First, we show that just after run-offs borrowers reduce their labor supply: our point estimates suggest that individuals reduce labor income by 39 percent of the amount previously devoted to

\footnotetext{
${ }^{2}$ Agarwal, Liu, and Souleles (2007), Agarwal and Qian (2014), Souleles (1999), Johnson, Parker, and Souleles (2006), and Hsieh (2003) are examples of papers that look at the consumption response to changes to income or cash on hand. Jappelli and Pistaferri (2010) survey theoretical results on the consumption response to income shocks, and Attanasio and Weber (2010) and Fuchs-Schuendeln and Hassan (2015) survey empirical results.
} 
mortgage payments. As suggestive evidence for the mechanism through which this decrease in earnings is happening, we show that an increasing proportion of individuals switch to parttime work after the run-off. Second, we find a faster repayment of other debts after the runoff: individuals devote 53 percent of their previous mortgage payment to reducing other debt. However, probably because most Danes save less in taxable or investments accounts relative to other countries, we find no statistically significant evidence of asset accumulation in bank deposits, stocks, or bonds. Danes are already subjected to compulsory savings scheme which place most of them at a "corner solution” in terms of savings. Chetty et al. (2014) estimate that a $\$ 1$ tax subsidy to pension savings only raises $\$ 0.01$ of additional pension savings by the Danish population - using virtually the same sample period - and that overall savings rates are driven by compulsory set savings levels, indicating that Danes are already at the pension saving limit.

Our results differ somewhat across sub-samples of potentially constrained and unconstrained individuals, providing suggestive evidence consistent with our theoretical intuition. However, the differences between these groups are not strongly significant, which makes evidence of these differences more suggestive than definitive. For borrowers without pre-run-off assets or other debt - for whom we would expect the savings constraint imposed by the mortgage to bind - labor income falls by 47 percent of freed up liquidity after the runoff. Borrowers had presumably been constrained to consume less leisure than they would have preferred prior to the run-off (and presumably lower consumption, though we cannot measure this directly). For these borrowers, we find no statistically significant change in other debts or assets. For borrowers without pre-run-off assets but with pre-run-off other debt, there is no statistically significant evidence of a reduction in labor income and we cannot reject the hypothesis that they cease borrowing to finance mortgage payments nearly one-for-one.

While the institutional setting of mortgage run-off on fixed rate mortgages will be familiar to U.S. readers, the data available on each household are much richer. We use administrative registry data from the Danish tax authorities covering the universe of Danish mortgages. We do not observe the mortgage terms explicitly, so we identify mortgage run-off as a mortgage with a balance that falls steadily to zero; given a penalty for prepayment, this will not reflect 
an individual consistently making larger-than-required payments each month. ${ }^{3}$ Nearly all mortgages that have run off in recent years were standard, 20- or 30-year fixed rate mortgages with 240 or 360 monthly payments of equal size. These mortgages differ from their counterparts in the U.S.A. in that they typically come with a prepayment penalty and are not discharged in foreclosure; these features imply that it is almost never optimal for borrowers to default or prepay in the years leading up to mortgage run-off when the mortgage balance is relatively low. Although more flexible mortgages have been available in Denmark in recent years, such mortgages are a decade or more from run-off.

This is not the first paper to consider run-offs. Coulibaly and Li (2006) use the Consumer Expenditure Survey (CEX) to measure the consumption and saving responses for 286 mortgage run-off events. The nature of the CEX allows them to analyze different categories of expenditures such as non-durables, home furnishing, entertainment, and vehicles. They find that for every US\$ 1 freed up from mortgage payments, consumers increase expenditures on house furnishing and entertainment by 20 cents and 4 cents, respectively, and increase savings by 32 cents. Stephens (2008) uses CEX data to measure the consumption response for approximately 200 car loan run-off events ${ }^{4}$. He finds that a $10 \%$ increase in after-tax income due to the run-off increases nondurable consumption by $2.8 \%$. Scholnick (2013) uses administrative data from a Canadian financial institution to measure the credit card spending response for 147 mortgage run-off events. He finds support for the magnitude hypothesis, which predicts that the magnitude of an anticipated income change affects consumption smoothing. d'Astous (2017) uses administrative data from a North American Bank to identify the credit card consumption and term loan uptake responses for 291,777 term loan run-off events. He finds that people increase credit consumption and term loans by 9 cents and 15 cents on the dollar, respectively.

Table 1 summarizes the major features and results of these papers and compares them with our study, with an attempt to standardize the way results are expressed so that magnitudes are comparable. Our data include a large number of run-off events (as in

\footnotetext{
${ }^{3}$ In our data, we do not observe the mortgage balance. Rather, we observe the value of the component of the mortgage backed security attributable to that mortgage. This value represents the mortgage balance, adjusted for the gap between the interest rate on the mortgage and the current market interest rate for mortgages with that maturity. We have data on mortgage-backed security prices to infer the mortgage balances from these data. These calculations can be made more precise using data on the annual mortgage interest paid.

${ }^{4}$ About $4 \%$ of an original sample of 5,000 according to Table 1 presented in the paper.
} 
d'Astous), high-quality administrative data (as in Scholnick and d'Astous) spanning all financial institutions (unlike Scholnick and d'Astous who have data from one bank each), and a full range of earnings and household balance sheet outcomes not available in other data used to study mortgage run-offs. While our data have a number of advantages in data quality, size, and breadth, we complement the expenditure outcomes that are well-covered by credit card spending (Scholnick and d'Astous) and survey responses in the CEX (Stephens and Coulibaly and Li). Our data allows the first analysis of the effect of run-off on earnings and the complete household balance sheet as measured by administrative data.

\section{Theoretical Framework}

Mortgages can be seen as saving commitments that tie a portion of households' disposable income to saving in the form of mortgage principal payments. If we think of mortgages as negative bonds -bonds that homeowners sell to investors - then paying down mortgage principal reduces the holding of such negative bonds. Mortgage repayment schedules therefore impose to borrowers a saving commitment.

We use this setting to make predictions about how rational, forward-looking, risk-averse individuals would respond to a saving commitment being relaxed in a predictable manner. These predictions are derived using elements of the literature on the Permanent Income Hypothesis, PIH henceforth (Modigliani and Brumberg, 1954; Friedman, 1957), and of the literature on liquidity constraints (e.g, Zeldes, 1984; Carroll, 2001; Deaton, 1991).

Our framework borrows from Stephens (2008), which applies this class of models to study an auto loan debt run-off; his results in the context of auto loans apply equally to mortgage run-offs. His model has three periods; in the first period consumers borrow to finance a car loan, in the second period they repay the loan and in the third period they consume what is left. We lay out a model with consumption and labor supply decisions, which illustrates the effects of mortgage run-offs on consumption, savings, borrowing, leisure and earnings, for constrained and unconstrained consumers. Our model extends Stephens (2008) in two ways, but is otherwise identical to it in structure and notation: first, Stephens (2008) assumes that consumers cannot borrow in the second period, and second he does not include the labor supply decision. 


\section{a. Model Setup}

Consider a simple model with no uncertainty in which homeowners choose non-housing consumption and labor in each of three periods. In the first period $(t=1)$, consumers also choose a home and a mortgage. In the second period ( $t=2)$, consumers pay off that mortgage and may additionally borrow or save outside the mortgage; this corresponds to the pre-runoff period in our statistical analysis. In the final period $(t=3)$, consumers pay off any outstanding non-mortgage debt or consume the proceeds from previous saving; this corresponds to the post-run-off periods in our statistical analysis.

In period 1 , consumers buy a house of value $H$. They can finance a fraction $0 \leq \phi \leq 1$ of the house through a mortgage loan at rate $r^{b}$, with $\phi H\left(1+r^{b}\right)$ to be repaid in the second period. In the first two periods consumers can save at a rate $r^{l}$, where $r^{l}<r^{b}$, while in the final period all resources are consumed. If income in the second periods does not meet consumption needs, the consumers can also choose to borrow at a rate $r^{c}$, where $r^{b}<r^{c}$.

In all periods consumers choose how much to consume $\left(C_{t}\right)$ and how much to work $\left(L_{t}\right)$. They derive utility from consumption and leisure $\left(Z_{t}\right)$, and both are assumed to be normal goods. We normalize the maximum possible labor supply to 1 , such that $L_{t}+Z_{t}=1$. In each period, felicity $u\left(C_{t}, Z_{t}\right)$ is a function of consumption and leisure. ${ }^{6}$ Consumers maximize the sum of utility from housing $V(H)$ and utility in each period, $u\left(C_{t}, Z_{t}\right)$, discounted at a rate $\beta$. Wages are set to $w_{t}$ in period $t$; individuals earn $y_{t}=L_{t} w_{t}$ in period $t$. Stephens (2008) assumes no labor supply decision, which corresponds to setting $L_{t}=1$ in our model.

\footnotetext{
${ }^{5}$ We assume that total borrowing can never exceed the value of the house, so consumers cannot borrow outside the mortgage in period 1 when $\phi=1$. In periods 1 and 2, consumers will either save, borrow, or neither; they will never choose to both borrow and save simultaneously since $r^{l}<r^{b}$ (relevant for period 1) and $r^{l}<$ $r^{c}$ (relevant for period 2). Stephens (2008) assumes that consumers cannot borrow in the second period, which gives the same result as setting $r^{c}=\infty$ in our model.

${ }^{6}$ We make standard concavity assumptions, namely $u_{C}>0, u_{C C}<0$, and $u_{L}<0, u_{L L}>0$. We make no assumptions about $u_{C L}$, which governs separability between consumption and leisure, other than requiring that they are both normal goods. We follow Stephens (2008) in assuming separability in the utility derived from the durable asset (housing in our case).
} 


\section{b. Consumer's Optimization Problem}

Consumers maximize lifetime utility, $U$, by choosing consumption $\left(C_{t}\right)$ and leisure $\left(Z_{t}\right)$ in each period $t$, as well as house value $(H)$, and the share of that value financed by a mortgage $(\phi)$ in the first period. They solve the following problem:

$$
\max _{\left\{C_{1}, C_{2}, C_{3}, L_{1}, L_{2}, L_{3}, H, \varphi\right\}} U=u\left(C_{1}, Z_{1}\right)+\beta u\left(C_{2}, Z_{2}\right)+\beta^{2} u\left(C_{3}, Z_{3}\right)+V(H),
$$

subject to the constraint that total borrowing cannot exceed $\mathrm{H}$ in any period, and that all borrowing must be repaid in period 3. Consumers face the following laws of motion for borrowing and saving. In period 1 , consumers' net borrowing $\left(B_{1}\right)$ is defined as;

$$
B_{1}=C_{1}+H-L_{1} w_{1} \leq H
$$

Any borrowing in the first period will be mortgage borrowing $\left(\phi=B_{1} / H\right.$ for $\left.B_{1}>0\right)$, as non-mortgage borrowing is assumed to have a higher interest rate than mortgage borrowing $\left(r^{b}<r^{c}\right)$; saving in the first period $\left(B_{1}<0\right)$ is permitted by the model, but these cases are of less interest to us because they do not involve mortgages. In period 2, net borrowing $\left(B_{2}\right)$ is defined as;

$$
B_{2}=C_{2}-L_{2} w_{2}+\left(B_{1}\left(1+r^{l}\right) \mid B_{1}<0\right)+\left(B_{1}\left(1+r^{b}\right) \mid B_{1}>0\right) .
$$

$B_{2}$ depends on consumption $\left(C_{2}\right)$, labor income $\left(L_{2} w_{2}\right)$, as well as proceeds from saving $\left(B_{1}\left(1+r^{l}\right) \mid B_{1}<0\right)$ or mortgage repayment $\left(B_{1}\left(1+r^{b}\right) \mid B_{1}>0\right)$ from the first period. $B_{2}$ may be positive $\left(B_{2}>0\right.$, the level of non-mortgage debt), negative $\left(-B_{2}>0\right.$, the level invested wealth), or zero. In period 3, individuals consume remaining resources,

$$
C_{3}=L_{3} w_{3}-\left(B_{2}\left(1+r^{l}\right) \mid B_{2}<0\right)-\left(B_{2}\left(1+r^{c}\right) \mid B_{2}>0\right)
$$

\section{c. Labor-Leisure vs. Consumption Decision}

We assume an interior solution for leisure, so $0<Z_{t}^{*}<1$. Consumers always have the option to work slightly more and to consume the resulting income in the same period; at an optimum, such marginal adjustments do not increase or decrease utility. This implies the following first order condition for each period t,

$$
u_{Z_{t}}\left(C_{t}^{*}, Z_{t}^{*}\right)=w_{t} u_{C_{t}}\left(C_{t}^{*}, Z_{t}^{*}\right)
$$




\section{d. Saving-Borrowing vs. Consumption Decision}

At an optimum, in periods 1 and 2 consumers may choose to borrow, save, or neither. This yields nine possible types of equilibria, (3 options in the first period multiplied by 3 options in the second period). Since this paper explores mortgage run-offs, we only consider cases where mortgage borrowing is positive in the first period; there would be no mortgage run-offs to consider absent mortgage borrowing. As a result, we consider the three cases in which borrowers take out a mortgage in the first period; either borrowing, saving or neither in the second period. We consider each of the three possible equilibria in turn.

\section{i. $\quad$ Interior Solutions for "Unconstrained” Savers and Borrowers}

Consumers who choose to save or borrow in period 2 ( $B_{2}^{*}<0$ or $B_{2}^{*}>0$, respectively) could have chosen an alternative option to consume slightly more in period 2, save less or borrow more in period 2, respectively, and consume less in period 3. Similarly, they have the option to consume slightly less in period 2, save more or borrow less in period 2, respectively, and consume more in period 3. At an optimum, such marginal adjustments do not increase or decrease utility. This implies the following first order conditions for individuals saving or borrowing in period 2, respectively:

$$
\begin{gathered}
\beta u_{C C_{3}}\left(C_{3}^{*}, Z_{3}^{*}\right)\left(1+r^{l}\right)=u_{C_{2}}\left(C_{2}^{*}, Z_{2}^{*}\right) \\
\beta u_{C_{3}}\left(C_{3}^{*}, Z_{3}^{*}\right)\left(1+r^{c}\right)=u_{C_{2}}\left(C_{2}, Z_{2}\right)
\end{gathered}
$$

For these consumers, the standard Euler Equation holds; the marginal utility of consumption is the same in the second and third periods. As a result, the size of the loan payment does not affect consumption, as larger loan payments are offset one-for-one by lower savings or greater borrowing elsewhere. Going into the run-off, unconstrained borrowers either draw down their non-mortgage savings or accrue non-mortgage debt to make the mortgage principal payments. When this stops after the run-off, net non-mortgage savings increase. We think about these consumers as being unconstrained because the first order conditions hold with equality; they have to ability to either save or borrow, respectively. 


\section{ii. Corner Solutions for "Constrained” Consumers Who Neither Save Nor Borrow}

Consumer who choose neither to save nor to borrow in the second period $\left(B_{2}^{*}=0\right)$ declined the option to save or borrow; marginal adjustments to saving must make the consumer at least weakly worse off. This implies the following first order conditions for those who choose to neither save nor borrow:

$$
\beta\left(1+r^{l}\right) u_{C_{3}}\left(C_{3}^{*}, Z_{3}^{*}\right) \leq u_{C_{2}}\left(C_{2}^{*}, Z_{2}^{*}\right) \leq \beta\left(1+r^{c}\right) u_{C_{3}}\left(C_{3}^{*}, Z_{3}^{*}\right)
$$

Note that at least one of the two weak inequalities must be a strict inequality because $r^{l}<$ $r^{c}$. We think about these consumers as being constrained in the sense that one or both of the first order conditions do not hold with equality. For constrained consumers, the marginal utility of consumption in period three is smaller than in period two, when the loan has to be repaid.

\section{e. Model Predictions}

How does the model predict labor income, non-mortgage borrowing, and saving to change between the pre- and post-run-off periods, and how should these changes be different for

those with larger and smaller mortgage payments $\left(\phi H\left(1+r^{b}\right)\right)$ ? Larger mortgages imply lower discretionary income in the second period, as more must be repaid.

How does the consumer adjust consumption and labor income in response to this reduction in discretionary income? For unconstrained consumers who save or borrow in period 2, the first order conditions continue to hold as the mortgage payment $\left(\phi H\left(1+r^{b}\right)\right)$ varies. Reduced discretionary income in the second period caused by a larger mortgage is shared between reduced consumption and reduced leisure in periods 2 and 3; there are no changes in relative consumption or leisure between periods 2 and 3. This is achieved through increased borrowing or reduced savings in period 2, leading to lower consumption in period 3 as the larger non-mortgage loan or smaller saving from period 2 leaves fewer resources available in period 3 when the loan must be repaid or the savings drawn down. In other words, larger mortgages will be associated with increased borrowing or reduced savings prior to a 
mortgage run-off but without a relative change in consumption, leisure or earnings between periods 2 and $3 .^{7}$

For constrained consumers, who neither save nor borrow in period 2, the brunt of reduced discretionary income in the second period caused by a marginally larger mortgages is borne entirely in period 2; both consumption and leisure in period 2 (since both are assumed to be normal goods) fall, without any adjustment to saving, borrowing, or period 3 consumption and leisure. In other words, larger mortgages will be associated with larger relative increases in consumption or leisure - and associated decreases in earnings - between periods 2 and 3 , without adjustments in savings or borrowing.

As Stephens (2008) notes, the borrowers' financial position at the time of run-off indicates whether the Euler Equation holds, and consequentially the nature of the expected consumption and saving response to the run-off. The Euler Equation holds when borrowers have the ability to take out more debt or run down their savings leading up to the run-off; the presence of savings or debt at the time of run-off provides suggestive evidence that these borrowers are unconstrained. ${ }^{8}$ Consumers who were constrained by the saving rate imposed by their mortgage can choose to borrow to fund consumption or not. For individuals who chose not to increase consumption early, we would predict that relaxing a saving constraint would lead to an increase in consumption (or an increase in leisure). ${ }^{9}$ For constrained consumers who had chosen to finance consumption through other debt prior to the mortgage run-off, we would predict that they would use the freed-up liquidity from mortgage payments to pay down their other accumulated debts.

\footnotetext{
${ }^{7}$ This setting abstracts from the run-offs we explore empirically by considering only one pre-run-off period (period 2) and only one post-run-off period (period 3). A more realistic model would include multiple pre- and post-run-off periods to show dynamics of debt and savings accumulation before and after the run-off. In a more realistic setting, the proportion of any consumption effects allocated pre- and post-run-off would be based on the number of periods pre- and post-run-off. This would affect the amount of borrowing needed to smooth consumption pre- and post-run-off for a given change in lifetime consumption.

${ }^{8}$ The Euler Equation might not hold for a borrower with assets at the time of run-off if those assets were held in a trust that the consumer could not access; similarly, it might not hold for a borrowers with debt at the time of run-off who had maxed out their ability to borrow at that rate. Such borrowers might be mis-identified as unconstrained by their asset position.

${ }^{9}$ Since the income expansion path can be of any monotonically increasing shape, it is theoretically plausible to get increases of consumption or leisure. Only in specific cases, such as perfect complements, one can make unambiguous predictions about the ratio of consumption to leisure.
} 


\section{Data}

\section{a. Data sources}

Our dataset includes demographic and financial information on the universe of adult Danes between 1986 and 2014. We derive data from two different administrative registers made available through Statistics Denmark: demographic information from the Danish Civil Registration System (CPR Registeret), and income and financial information from the Danish Tax Authority (SKAT).

Demographic information from the Danish Civil Registration System contains the entire Danish population. It includes the individuals' personal identification number as well as their gender, date of birth, and marital history. The personal identification number is unique for each individual in the population, and is used across all administrative datasets. The administrative records also contain a unique household identification number, as well as those of each individual's spouse and children in the household. We use these data to obtain basic demographical information about each individual and household.

Income and financial information from the Danish Tax Authority contains both the total and disaggregated income and wealth information for the entire Danish population. The Danish Tax Authority receives this information directly from the relevant third-party sources: employers supply statements of wages paid to their employees, and all financial institutions supply information on their customers' deposits, interests paid and received, security investments in stocks and bonds, and dividends. Because taxation in Denmark mainly occurs at the source level, this income and wealth information is highly reliable. For our purpose here, the records include the total outstanding mortgages at the end of the year, as well as the total interest payments paid on the mortgage within the year. Though this information is extensive, not all components of wealth are recorded by the Danish Tax Authority: we do not have information about individuals' holdings of unbanked cash, the value of their cars, their private debt (i.e., debt to private individuals), accumulated pension savings, private businesses, or other informal wealth holdings. 


\section{b. Methodology}

The mortgage run-offs we consider inherit the appealing econometric features of a regression discontinuity design (RDD) or regression kink design (RKD) (Lee and Lemieux, 2010). Mortgage run-offs remove a savings constraint; a borrowers' cash available jumps discontinuously when the mortgage runs off at a pre-specified time (Coulibaly and Li, 2006; Scholnick, 2013). The timing of this discontinuity is determined 20 or 30 years before when the mortgage is originated. We then examine the evolution of wealth from yeart0-3 to yeart0+3, where yeart 0 is the year in which the run-off occurs.

These RDD and RKD techniques were originally used by Thistlethwaite and Campbell (1960) to study the impact of merit awards on future academic outcomes, and has been recently applied to Norwegian register data by Kirkeboen et al. (2016) to study the impact of type and quality of education on income later in life. These methodologies rely on the assumption that individuals are unable to precisely manipulate their position around the discontinuity and effectively replicate a randomized experiment in which individuals would be randomly assigned to the treatment. In our case, because borrowers have committed to their mortgage repayment schedule many years ago, the actual date of their final payment can be considered quasi-exogenous to their financial condition in the years surrounding the run-off. As a practical matter, our annual data make high frequency analysis before and after the run-off difficult, since the run-off event can happen at any time of the year. Instead, our primary analysis focuses on a comparison of economic outcomes in the years before versus after the run-off.

However, because the mortgage could be refinanced (or prepaid, although at a cost), unobservable variables could correlate with the decision to refinance the mortgage and with other outcomes studied in the analysis. To overcome the fact that prepayment could create a selection problem, we look at mortgages whose balances appear on track to run off at year $t$ based on changes in balances in yeart0-6 to yeart0-3. The main analysis therefore uses the anticipated date of final payment — predicted three years before its realization — as the event relaxing the saving commitment. In this intention-to-treat (ITT) approach (e.g. Imbens and Rudin, 2015), random assignment into the treatment is assumed to hold for the predicted final payment date, not its actual realization. This intent-to-treat approach looks at mortgages on the glide path to run off, whether they actually run off or not. This allows us to observe 
households who take out a new mortgage just when their old mortgage is running out so that their total mortgage balance never falls to zero. This also mitigates concerns about unobservable variables correlating with the final payment and subsequent behavior, while still capturing a discontinuous change in annual required mortgage payments.

\section{c. Sample Construction}

We do not have the exact terms of the mortgages so we use the balance at the end of each calendar year (as proxied by the value of the mortgage backed security attributable to that mortgage) to identify expected run-off year and the estimated annual payment. We identify a mortgage as on track to run off in exactly three years if the following criteria are met: (i) The cumulative decline in the mortgage balance over the past three years (between six and three years before the expected run-off) must be similar to - between $80 \%$ and $120 \%$ of - the mortgage balance (three years before the expected run-off); and, (ii) The annual declines in the mortgage balance over the past three years (between six and five years, five and four years, and four and three years before the expected run-off) must be similar to - between $75 \%$ and $133 \%$ of - one another; ${ }^{10}$

Using this approach, we identify 77,790 individuals in the sample that have a mortgage on track to run off between 1995 and 2014 (that is, they have an expected run-off year between 2001 and 2011). Since we examine behavior in the three years before and after an expected run-off, the analysis includes data from 1998 (three years before the first expected run-off in the sample) to 2014 (three years after the last expected run-off in the sample). We define the estimated annual mortgage payment as one third of the balance three years prior to the expected run-off. We additionally impose three restrictions on the sample, where either identification of outcome variables are diffuse due to limits in the register data, or where identification of the treatment leads to very small run-offs. ${ }^{11}$

${ }^{10} 0.75 \leq \frac{\mathrm{Bal}_{6}-\mathrm{Bal}_{5}}{\mathrm{Bal}_{5}-\mathrm{Bal}_{4}} \leq 1.33$ and $0.75 \leq \frac{\mathrm{Bal}_{5}-\mathrm{Bal}_{4}}{\mathrm{Bal}_{4}-\mathrm{Bal}_{3}} \leq 1.33$

${ }^{11}$ The three restrictions are: (i) 17,111 individuals (22 percent of our initial sample) who receive any small income from privately owned companies. We exclude these self-employed individuals because they can use their companies as a saving mechanism in the sense that they can decide to take out or not earnings from the companies for tax reasons. This is in effect an important saving mechanism that could be affected by mortgage run-offs and that we cannot observe in the Danish registers. (ii) We exclude 1,043 individuals (1.3 percent of our initial sample) with either large ( $>1$ million DKK) year-to-year changes in net financial wealth or extremely large ( $>10$ million DKK) housing wealth. (iii) Finally we exclude 55,301 individuals (71 percent of our initial sample) with small mortgage payments relative to their income (estimated annual mortgage payments less than 10 
After imposing these restrictions, our final sample consists of 15,895 individuals. ${ }^{12}$ These individuals show mortgage balances that fall mechanically between six and three years prior to the expected run-off year (Figure 1). The median mortgage balance falls to zero in the expected run-off year (Figure 1.a) and the share of mortgages with zero balance jumps discontinuously from less than 20 percent in the year prior to the expected run-off to more than 50 percent in the year of the expected run-off (Figure 1.b).

A possible challenge of our identification strategy is the possibility that individuals time the maturity of their mortgage contract with other life-cycle events, such as their anticipated year of retirement. Although we do not observe the historical mortgage contract terms in our main dataset, we use current mortgage loan contract data, which includes mortgage contract terms for the universe of active mortgages in Denmark in the period 2009-2014, and match these to the active mortgages in our main data in year 2009. ${ }^{13}$ Figure 2 shows the distribution of mortgage maturities at origination for these mortgages. $74.5 \%$ of the mortgage maturities falls exactly into 5-year bins finishing either in 0 or 5 . Mortgages are issued quarterly and $17.5 \%$ of the maturities fall one year short from 0 or 5 year bins (i.e. they finish with either $1,2,6$, or 9) due to issuing calendar rounding's. Only $8 \%$ of the mortgage maturities finish with either $2,3,7$, or 8 . This suggests that the vast majority of the mortgages maturities are chosen as standard lengths, or within one year of that, ruling out maturities strategically chosen with respect to the run-off year. While $8 \%$ of the mortgage maturities may seem nonstandard and potentially strategically selected, a 30 year mortgage refinanced after 18 years could also give rise to a 12-year maturity non-strategically chosen mortgage contract. ${ }^{14}$

\section{[INSERT FIGURE 1 ABOUT HERE]}

percent of average of annual labor income between five and three years before the expected run-off). We exclude these small mortgages from our baseline analysis to focus on mortgages that are economically significant to borrowers. Additional robustness checks in Section 5 exploit these small mortgages to perform a placebo test.

${ }^{12}$ When our regressions have the individual's working status as the outcome we further drop 8,968 individuals for whom the working status is missing.

${ }^{13} 3,688$ mortgages from our main sample are still active in 2009.

${ }^{14}$ Mortgages is issued in series each quarter, in large pools. Historically, asking for a mortgage with nonstandard maturity (coupon rate or other contract term) results in a small amount of bonds with these characteristics. This causes the bond itself to become illiquid in the market. As a mortgage owner you want your mortgage to be as liquid in the market as possible, because it gives you the largest possibility to gains better terms when refinancing your mortgage. 
Table 2 presents descriptive statistics for the sample used in the analysis. All variables are recorded at the end of the calendar year and are measured three years prior to the year in which the mortgage is paid off. All monetary amounts are expressed in Danish kroner (DKK). ${ }^{15}$ Panel A. shows that our sample consists of individuals who are on average 57 years old, approximately 61\% of which are male, with about 2 adults in the household and out of which $73 \%$ are married, $7 \%$ are divorced and $41.5 \%$ are retired. Panel B. shows that the average annual labor income is about 222,000 Danish kroner (DKK). Pension income (payouts from pension retirement funds) is on average 49,000 DKK a year, (although people that have not retired have zero pension payouts). The total contributions to pensions are on average about 21,000 DKK a year. Panel C. shows the financial assets and liabilities (beyond mortgages). Individuals in our sample keep on average 91,000 DKK in liquid bank deposits, 35,000 DKK in stocks, 52,000 DKK in bonds and 32,000 DKK in loans. Panel D shows that housing assets are on average 1,007,000DKK, with a mortgage value of about 134,000DKK and mortgage payments of about 34,000DKK a year. These payments represent on average about $22 \%$ of the individual's labor income.

\section{[INSERT TABLE 2 ABOUT HERE]}

\section{d. Identification of behavioral change}

We analyze individual responses using a simple event-study methodology to predict values for individual $i$, at run-off time $t$ with the following estimating equation:

$$
\begin{aligned}
& Y_{i, t}=\beta_{1} \text { After }_{i, t} \times \overline{\text { Payment }}+\beta_{2} \text { After }_{i, t} \times\left(\text { Payment }_{i}-\overline{\text { Payment }}\right) \\
& + \text { CalendarYear F.E. }+f(t)+\alpha_{i}+\varepsilon_{i, t} \text {, }
\end{aligned}
$$

where $Y_{i, t}$ is either annual labor income in year $t$ or the annual change in a financial balance

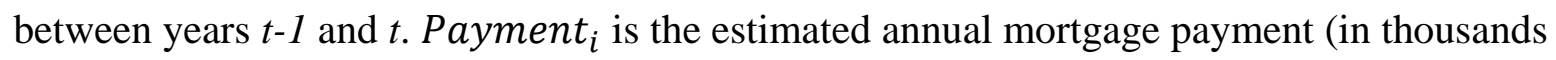
of DKK) calculated as the value of the mortgage three years prior to the anticipated final payment divided by three; $\overline{\text { Payment }}$ is the average value of the payment in the regression sample. The dummy variable After is equal to 1 if the year is one, two, or three years after the anticipated final payment and 0 if it is one, two, or three years before. We omit the year

\footnotetext{
15 The exchange rate between DKK and U.S. dollar was $14.94 \%$ at the beginning of our sample in 1998 , averaged $16.27 \%$ over the sample and was $17.81 \%$ at the end of our sample in 2014 . We use nominal values since mortgage payments and balances, and hence our run-off calculations, are based on nominal values. We control for inflation in our regressions with calendar year fixed effects.
} 
in which the payment is anticipated to end to circumvent the fact that different mortgages run out at different times in the year and therefore individuals benefit from different levels of increased liquidity within that year. An individual-level dummy variable $\left(\alpha_{i}\right)$ which absorbs all time-invariant effects at the individual level and calendar-year dummies $\left(\lambda_{t}\right)$ that absorb year effects are included in all specifications unless otherwise specified. Finally, $f(t)$ consists of the linear run-off year and its interaction with the size of annual mortgage payment, to control for potential linear trends in event-study time. Standard errors are clustered at the individual level.

This specification allows two different strategies - both intended to reveal the causal effect of the run-off on the outcomes of interest - to be shown and compared in the same regression. The coefficients $\beta_{1}$ and $\beta_{2}$ both show what fraction of the wealth freed up by the mortgage run-off is allocated to the outcome of interest.

The first (and simplest) identification strategy is a before- versus after-run-off comparison; we scale the After $_{i, t}$ variable by the size of the average mortgage payment ( $\overline{\text { Payment }}$ ) so that its coefficient $\left(\beta_{1}\right)$ can be interpreted as the before- versus after-run-off change in the outcome of interest as a proportion of an average-sized mortgage payment. For this before- versus after-run-off to accurately measure the causal effect of a run-off, the location of the discontinuity must be uncorrelated with the errors. In our case, a comparison of pre- and post-run-off behavior will only reveal the true effect of relaxing the saving constraint if the exact timing of the run-off is exogenous. Given that the exact run-off date had been chosen many years in the past - typically among a set of round-numbered options - this assumption appears relatively benign.

The second (and our preferred) identification strategy allows a weaker assumption about the endogenous timing of run-offs by comparing the before- and after-run-off patterns in the outcome of interest for those with small and large mortgages. We examine how economic outcomes change post-run-off as mortgage payment size - and with it, the amount of wealth freed up by the run-off - gets bigger. The coefficient on the After $_{i, t} \times\left(\right.$ Payment $_{i}-$ $\overline{\text { Payment }}$ ) interaction $\left(\beta_{2}\right)$ captures how the before- versus after-run-off difference in the outcome of interest change as the size of the mortgage payment increases. The coefficient $\beta_{2}$ has the appealing interpretation of showing how an additional kroner of mortgage payment is allocated after the run-off, comparing smaller mortgages to larger ones. This identification 
strategy will be unbiased as long as there are no differences between large and small mortgages in the degree to which run-off timing is endogenous.

\section{Results}

We present our baseline results in Table 3, estimating equation (1) with labor income and changes in bank account, stock, bond, and bank loan balances. We find that on average individuals adjust only two of the margins we study: labor income and other bank loans. We find no statistically significant evidence of differences in stock, bond, or bank account balance accumulation before versus after the run-off.

The estimated coefficients on After $_{i, t} \times \overline{\text { Payment }}\left(\beta_{1}=-0.14\right.$, 95\% C.I. -0.20 to - 0.087) and After $_{i, t} \times\left(\right.$ Payment $\left._{i}-\overline{\text { Payment }}\right)\left(\beta_{2}=-0.39,95 \%\right.$ C.I. -0.67 to -0.10$)$ provide two different estimates of the share of the wealth freed up by a run-off that is offset by a subsequent reduction in labor income. For an average 34,000 DKK mortgage payment, these estimates indicate that labor income drops by approximately 5,000 DKK or 13,000 DKK (2 percent and 6 percent of average annual income) following the run-off, respectively. These estimates suggest that 14 percent or 39 percent of the money freed up by the run-off is “spent” on increased leisure (e.g., working fewer hours or earning less per hour - probably in a job with less intensity).

Figure 3 provides evidence for the mechanism driving the earnings adjustment. Using a variable identifying whether individuals are part-time workers, we show that the fraction of individuals with a larger-than-average mortgage payment are increasingly working part-time after the run-off. The share of borrowers with smaller-than-average mortgage payments working part-time does not change.

Bank loans are typically large and infrequent, which increases the estimation error on our estimated effect of run-offs on changes in bank loan balances. Our direct before versus after comparison shows no statistically significant evidence that run-offs affect changes in bank loan balances (coefficient on After $_{i, t} \times \overline{\text { Payment }} \beta_{1}=-0.09$, 95\% C.I. -0.23 to 0.043). However, comparing smaller and larger mortgages before and after the run-off indicates that 53 percent of the additional wealth freed up by larger mortgage payments after the run-off 
goes to reduced debt accumulation (coefficient on $A$ fter $_{i, t} \times\left(\right.$ Payment $\left._{i}-\overline{\text { Payment }}\right) \beta_{2}=$ $-0.53,95 \%$ C.I. -1.00 to -0.050$)$.

\section{[INSERT TABLE 3 ABOUT HERE]}

Because theory suggests individuals with different assets and debt should respond differently to a relaxation of the saving constraint, we divide our sample into four groups depending on people's financial position three years prior to the run-off (when we predict the expected run-off year) and re-estimate our baseline equation for each group. Table 4 presents the results. Panel A. consists in the subsample of individuals with no financial assets (i.e., no stock nor bond holdings) and no bank loan debt; Panel B. consists in individuals that had at least some stocks and bonds or accumulated debt; and Panels B1 through B3 refine the groups of individuals with at least some stocks and bonds or accumulated debt into three further groups (i.e., Panel B1. for individuals with no financial assets but with bank loan debt; Panel B2. for individuals with financial assets (i.e., some stock or some bond holdings) and no bank loan debt; and Panel B3. for individuals with financial assets and bank loan debt). ${ }^{16}$

\section{[INSERT TABLE 4 ABOUT HERE]}

The reduction in labor supply found in the average results is driven by individuals who had no assets and no other debt at the moment of the run-off. A simple before versus after comparison shows that the before- versus after-run-off difference in labor income is 16 percent of the size of a typical mortgage run-off (coefficient on After $_{i, t} \times \overline{\text { Payment }} \beta_{1}=$ $-0.16,95 \%$ C.I -0.23 to -0.091 ). Our comparison exploiting differences in mortgage payment size suggests that as mortgage payments - and with them, the amount of money freed up by the run-off) increase, the before- versus after-run-off difference in labor income is reduced by 47 percent of that amount (coefficient on After $_{i, t} \times\left(\right.$ Payment $\left._{i}-\overline{\text { Payment }}\right)$ $\beta_{2}=-0.47,95 \%$ C.I. -0.74 to -0.19$)$. Because these individuals have neither substantial assets not debts in the years prior to the run-off, they may be "hand to mouth" consumers who consume all disposable income. They are the most likely to be constrained by the

\footnotetext{
${ }^{16}$ Specifically, individuals are identified as holding stocks and bonds if the value of their end-of-year stocks and bonds holdings combined is higher than 50,000DKK on average six to three years before the predicted final payment. Similarly, they are identified as having bank loan debt if their end-of-year debt is higher than $50,000 \mathrm{DKK}$ on average six to three years before the predicted final payment.
} 
savings constraints imposed by the mortgage, or to act as if they are constrained. For this group, we show evidence that a non-trivial share of the money freed up by the run-off goes to increased leisure, as proxied by reduced labor income. The labor supply responses for those with assets or debts prior to the run-off are generally small and statistically indistinguishable from zero, consistent with a view that the consumption (of goods or leisure) is not constrained by their schedule of mortgage payments

The noisiness of bank loan data limits our ability to cleanly identify different effects of the run-off on changes in bank loans for different groups. However, examining individuals with debts but not assets prior to the run-off provides some evidence that this group merely substitutes paying off mortgage debt for paying off other debt one-for-one. Comparing the before- versus after-run-off changes in bank loan balances by mortgage payment size, larger mortgage payments are associated with larger reductions in bank loans after the run-off. While estimates are noisy, we cannot reject the hypothesis that the offset is one-for-one

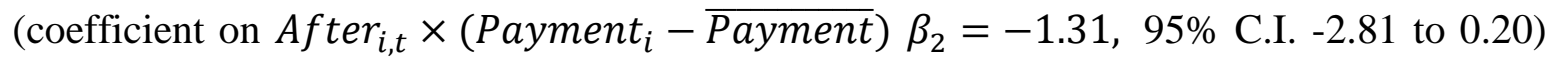
While simpler before versus after comparisons yield smaller and insignificant estimates, such estimates are potentially problematic to interpret when splitting the sample on pre-run-off debt (coefficient on After $_{i, t} \times \overline{\text { Payment }} \beta_{1}=0.13$, 95\% C.I. -0.26 to 0.52). While the timing of the run-off may be exogenous, the timing of pre-run-off debt accumulation may not be, making those that take out debt in the six to three years prior to the run-off a highly selected and non-random group with respect to their plans to pay down bank debt after the run-off .While these results compare outcomes before and after the run-offs, they say little about the year-to-year dynamics of labor income or changes in bank loans in the years surrounding the run-offs.

To better understand the dynamics of our outcomes of interest, Figure 4 plots run-offyear-specific coefficients from regressions that mirror the ones in Tables 3 and 4, replacing After $_{i, t}$ dummy variables (and their interaction with mortgage payment) with dummy variables for each run-off year (and their interaction with mortgage payment). ${ }^{17}$ Labor incomes are relatively smooth in the years prior to the run-off and the level of labor income

\footnotetext{
17 The regressions used to construct Figures 2 and 3 only include controls for the number of years since runoff (either as dummies or in linear form in columns 1) or their interaction with the annual mortgage payment (in columns 2).
} 
does not jump at the run-off year (top Panel of Figure 4). Instead, the slope gets steeper (more negative) after the run-off so that labor incomes drop faster year-to year after the runoff. While this finding is inconsistent with a classic life-cycle model in which leisure could be adjusted costlessly, it could be explained by an increased rate of search for (and therefore switching to) lower-pay or lower-hours work after the run-off.

Changes in bank loans increase sharply in the three years prior to the run-off, as borrowers accumulate debt to finance required mortgage savings, and then this debt accumulation stops abruptly after the run-off (bottom Panel of Figure 4). This pattern can be understood as an attempt to circumvent the saving forced by the mortgage payment schedule in the final years of the mortgage to smooth consumption or other saving.

\section{Robustness Checks}

\section{a. Retirement and pension savings}

Because the timing of mortgage run-offs could coincide with the timing of retirement, we investigate the robustness of our results in the sub-sample of individuals that do not retire during the event-study. In this context, changes to labor income can be interpreted as changes along the intensive margin. Table A1 shows the results of estimating equation (1) for individuals that do not retire at any point in time. The results show that individuals without any assets nor debt still decrease their labor income once the mortgage runs off (coefficient on After $_{i, t} \times\left(\right.$ Payment $\left._{i}-\overline{\text { Payment }}\right), \beta_{2}=-0.56$, ), and individuals with no assets but some accumulated debt use the resources freed up by the mortgage run-off to pay down their debt (coefficient on After $_{i, t} \times\left(\right.$ Payment $\left._{i}-\overline{\text { Payment }}\right), \beta_{2}=-2.92$, ).

To further quantify the extensive margin of the labor supply decision, Table A2 presents the coefficients from logit regressions on the probability of retiring and becoming unemployed. Retirement and unemployment are defined as going from unretired to retired and employed to unemployed in a given year, respectively. ${ }^{18}$ The results show no statistically different propensity to retire once the mortgage runs off.

\footnotetext{
18 Being employed is defined as receiving labor income during the calendar year, alternatively, being unemployed is defined as any form of unemployment (including being on leave for maternity or medical reasons, being a student, being retired or being on poverty cash benefits).
} 
Finally, because individuals near retirement could also use their pension savings as an adjustment margin, Table A2 also presents OLS regressions on pension outflows and inflows. The simple before versus after comparison shows that the before- versus after-run-off difference in pension outflows is about 5.5\% while that of pension inflows is $-4.7 \%$ (coefficients on After $_{i, t} \times \overline{\text { Payment }} \beta_{1}=0.055$, 95\% C.I 0.026 to 0.083 , and $\beta_{1}=$ -0.047 , 95\% C.I -0.086 to -0.0084, respectively), although our preferred specification exploiting the size of mortgage payments provides no evidence of adjustments through pension savings inflow nor outflows.

\section{b. New mortgages}

Individuals could also contract new mortgages (or prepay their current mortgage) as a way to adjust their consumption-savings plan. In such cases, we would not expect to find adjustments along other savings margin if the substitution is from a mortgage that is running off to a new mortgage. To test this hypothesis, we estimate the propensity to take out a new mortgage (defined as an increase in mortgage balance greater than 500,000 DKK in a given year, i.e. the extensive margin) and on the size of any mortgage (i.e. the intensive margin). Table A3 shows a decrease in the propensity to take out a new mortgage when comparing the years before and after the original mortgage runs off, although our preferred specification exploiting the size of mortgage payments provides no evidence of adjustments through new mortgage loans.

\section{c. Robustness to compliance schemes}

Our main analysis uses the predicted date of mortgage run-off as the event relaxing the savings constraint, which can be interpreted as estimating the causal effect as an intent-totreat. Because such compliance scheme should not affect the estimated effects we find, in this section we re-estimate our baseline equation (1) using different compliance schemes. We calculate the same models as presented in Table 3 but we impose additional further restrictions of decreasing mortgage balances up to (i) two years prior to the predicted run-off year, (ii) one year prior to the predicted run-off year, and (iii) the year of the run-off event. These three alternative definitions of compliance make tighter restrictions of our baseline definition of glide path where we only require individuals to have decreasing mortgage balances in year six through three prior to run-off. Table A4 shows that our results about 
decreasing labor income and bank loans are robust to the different specifications of compliance.

We also test the robustness of our main findings to the econometric specification used. We re-estimate our main effects on changes in labor income and bank loans using different controls in Table A5. The results of columns (4) and (5) show that it is important to control for linear event-time and its interaction with the size of the mortgage payment to control for potentially different trends across individuals with high and low mortgage payments.

\section{d. Analysis of Couple-Level Balance Sheets}

In our main analysis, the unit of observation is an individual. In cases where both spouses within a household have their names on the mortgage contract the value of the mortgage is split across these two individuals in the data. Because there could be interactions in the labor supply decision within households, we re-estimate our main specifications by grouping individuals in three different ways. First, we sum up all studied outcomes at the householdlevel (whether the mortgage is held by only one of the spouse or both), second we sum up all studied outcomes at the household level only when both spouses are on the mortgage contract, and finally we look at the spouses for which the mortgage contract only appears under their partner’s name (“non-run-off spouses”).

The results of Table A6 show no effect of the mortgage run-off for non-run-off spouses (Panel C.). This suggests that within a household the spouses make separate financial decisions. Because the non-run-off spouses show no statistically significant effect, including them in the household-level analysis mostly adds noise (Panel A.). Looking at householdlevel outcomes but excluding non-run-off spouses yields qualitatively and quantitatively similar results as our main analysis (Panel B.).

\section{e. Placebo analysis}

Finally, our main analysis excludes individuals for whom the mortgage payment as a fraction of their labor income is lower than 10\%. For these individuals, we do not expect the mortgage run-off to relax a quantitatively important saving constraint. If this is the case, such individuals can be used in a placebo analysis where we compare their behavior before and after the mortgage run-off to the behavior of individuals for whom the mortgage payment is 
substantial (i.e. higher than $10 \%$ of their labor income). To this end, we re-estimate our main specification on the entire sample of individuals for whom we identified a mortgage run-off $(60,114$ individuals, excluding those who receive company income or have large financial wealth changes) and we identify the individuals with payments higher than $10 \%$ of their income (which compose our main sample) using a dummy variable called High Pmts. The results, presented in Table A7, show that while individuals with small mortgages reduce their labor income by about 1,870 DKK a year, individuals with high mortgage payments reduce it more, by a total of 4,650 DKK a year. Concerning bank loans, individuals with small mortgage reduce bank loans by about 2,160 DKK a year, a quantitatively small response when compared to the results from our main sample of individuals with high mortgage payments that suggest that $50 \%$ of resources previously going to mortgage payments (about 15,000 DKK) go to reducing previously accumulated debt in.

\section{Conclusions}

This paper documents consumers' responses to a change in saving commitments. Because mortgages commit borrowers to a repayment schedule that pays down their mortgage balance, a mortgage run-off relaxes a saving commitment. This saving commitment does not bind for consumers who choose to save more than is required by the mortgage contract or who borrow elsewhere to undo the saving requirement of the mortgage. Theory predicts that such consumers should not adjust their consumption but should increase savings or decrease debt with mortgage payments once they cease. We find that individuals with pre-run-off debts (but without pre-run-off assets) - for whom the mortgage saving commitment should not bind - perfectly offset the end of the mortgage saving commitment by paying down other debt post-run-off one-for-one. For this subset of borrowers, they work around the saving constraint of the mortgage just as theory would suggest.

Borrowers with neither pre-run-off savings nor other debt are most likely to be constrained by the mortgage saving requirement to save more and spend less than they would like prerun-off. We find that these borrowers reduce labor supply post-run-off, increasing their consumption of leisure once they are no longer forced to saving by paying down their mortgage balance. The savings constraint imposed by the mortgage binds for these borrowers. 


\section{References}

Agarwal, S., Chunlin Liu, C., and Souleles, N.S., "The Reaction of Consumer Spending and Debt to Tax Rebates-Evidence from Consumer Credit Data,” Journal of Political Economy, 115(6), 2007, 986-1019.

Agarwal, S., and Qian, W., “Consumption and Debt Response to Unanticipated Income Shocks: Evidence from a Natural Experiment in Singapore,” American Economic Review, 104(12), 2014, 4205-4230.

Attanasio, O.P., Weber, G., “Consumption and Saving: Models of Intertemporal Allocation and Their Implications for Public Policy,” Journal of Economic Literature, 48(3), 2010, 693-751.

Carroll, C. D., “Buffer-Stock Saving and the Life Cycle-Permanent Income Hypothesis,” Quarterly Journal of Economics, 112(1), 1997, 1-55.

Carroll, C. D., “A Theory of the Consumption Function, with and without Liquidity Constraints,” Journal of Economic Perspectives, 15(3), 2001, 23-45

Chetty, R., J. N. Friedman, S. Leth-Petersen, T. H. Nielsen, and T. Olsen, “Active vs. Passive Decisions and Crowd-Out in Retirement Savings Accounts: Evidence from Denmark,” Quarterly Journal of Economics, 129(3), 2014, 1141-1219.

Coulibaly, B. and G. Li, “Do Homeowners Increase Consumption after the Last Mortgage Payment? An Alternative Test of the Permanent Income Hypothesis,” Review of Economics and Statistics, 88(1), 2006, 10-19.

d’Astous, P., "Responses to an Anticipated Increase in Cash-on-Hand: Evidence from Term Loan Repayments,” Working Paper, HEC Montreal, 2016.

Deaton, A., “Saving and Liquidity Constraints,” Econometrica, 59(5), 1991, 1221-1248.

Fuchs-Schuendeln, N. and Hassan, T.A., "Natural Experiments in Macroeconomics," NBER Working Papers 21228, National Bureau of Economic Research, Inc, 2015.

Friedman, M., “The Permanent Income Hypothesis,” In A Theory of the Consumption Function, Princeton University Press, 1957, 20-37.

Hsieh, C.T., “Do Consumers React to Anticipated Income Changes? Evidence from the Alaska Permanent Fund,” American Economic Review, 93(1), 2003, 397-405.

Imbens, G. W. and D. B. Rundin, Causal Inference for Statistics, Social, and Biomedical Sciences, Cambridge University Press, 625 pages, 2015.

Jappelli, T. and L. Pistaferri, “The Consumption Response to Income Changes,” Annual Review of Economics, 2, 2010, 479-506. 
Johnson, D.S., Parker, J.A., and Souleles, N.S. "Household Expenditure and the Income Tax Rebates of 2001,”American Economic Review, 96(5), 2006, 1589-1610.

Kirkeboen, L., Leuven, E., and Mogstad, M. "Field of Study, Earnings, and Self-Selection," Quarterly Journal of Economics, Forthcoming, 2016.

Lee, D.S. and Lemieux, T., "Regression Discontinuity Designs in Economics,” Journal of Economic Literature, 48(2), 2010, 281-355.

Modigliani, F., and Richard H. Brumberg, "Utility Analysis and the Consumption Function: an Interpretation of Cross-section Data,” in Kenneth K. Kurihara, ed., PostKeynesian Economics, New Brunswick, NJ. Rutgers University Press, 1954, 388-436.

Scholnick, B., “Consumption Smoothing after the Final Mortgage Payment: Testing the Magnitude Hypothesis,” Review of Economics and Statistics, 95(4), 2013, 1444-1449

Souleles, N.S., “The Response of Household Consumption to Income Tax Refunds,” American Economic Review, 89(4), 1999, 947-958.

Stephens, M. J., “The Consumption Response to Predictable Changes in Discretionary Income: Evidence from the Repayment of Vehicle Loans,” Review of Economics and Statistics, 90(2), 2008 241-252.

Thistlethwaite, D.L., and Campbell, D.T., "Regression-discontinuity Analysis: An Alternative to the Ex post Facto Experiment,” Journal of Educational Psychology, 51(6), 1960, 309-331.

Zeldes, Stephen P. (1984): “Optimal Consumption with Stochastic Income,” Ph.D. thesis, Massachusetts Institute of Technology.

Zeldes, S. P., “Consumption and Liquidity Constraints: An Empirical Investigation,” Journal of Political Economy, 97(2), 1989 305-346. 
Figure 1. Mortgage Run-offs Identification

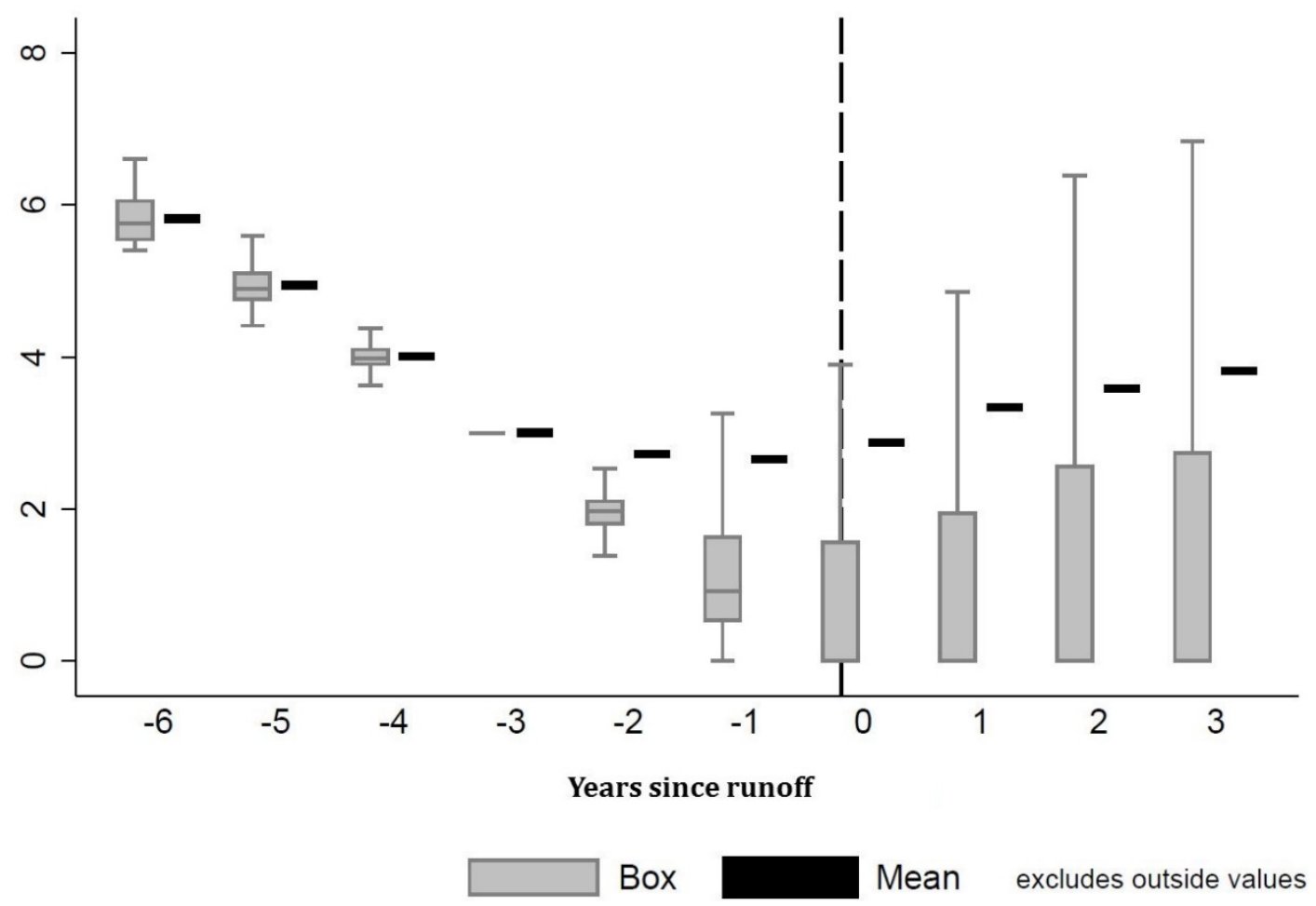

a) Mortgage value as a proportion of its value three years prior to the final payment

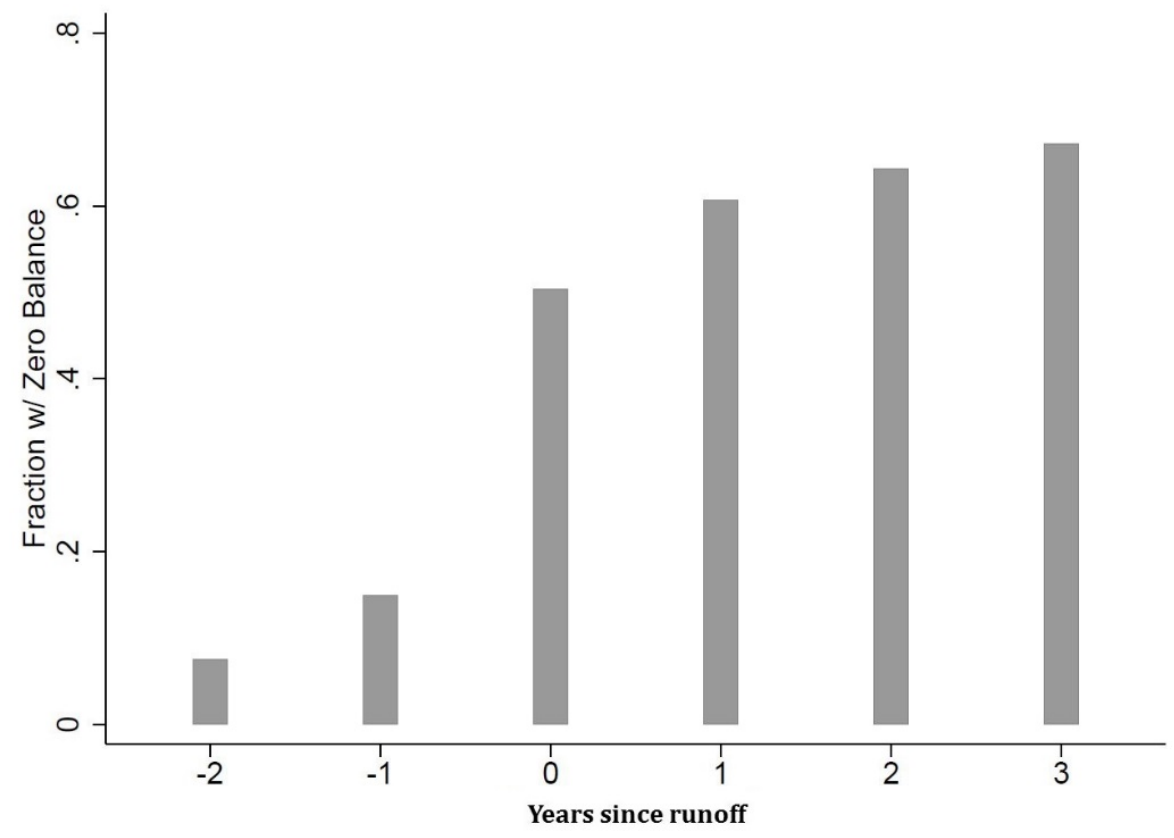

b) Proportion of individuals with a zero mortgage value 
Figure 2. Mortgage Maturities at Origination

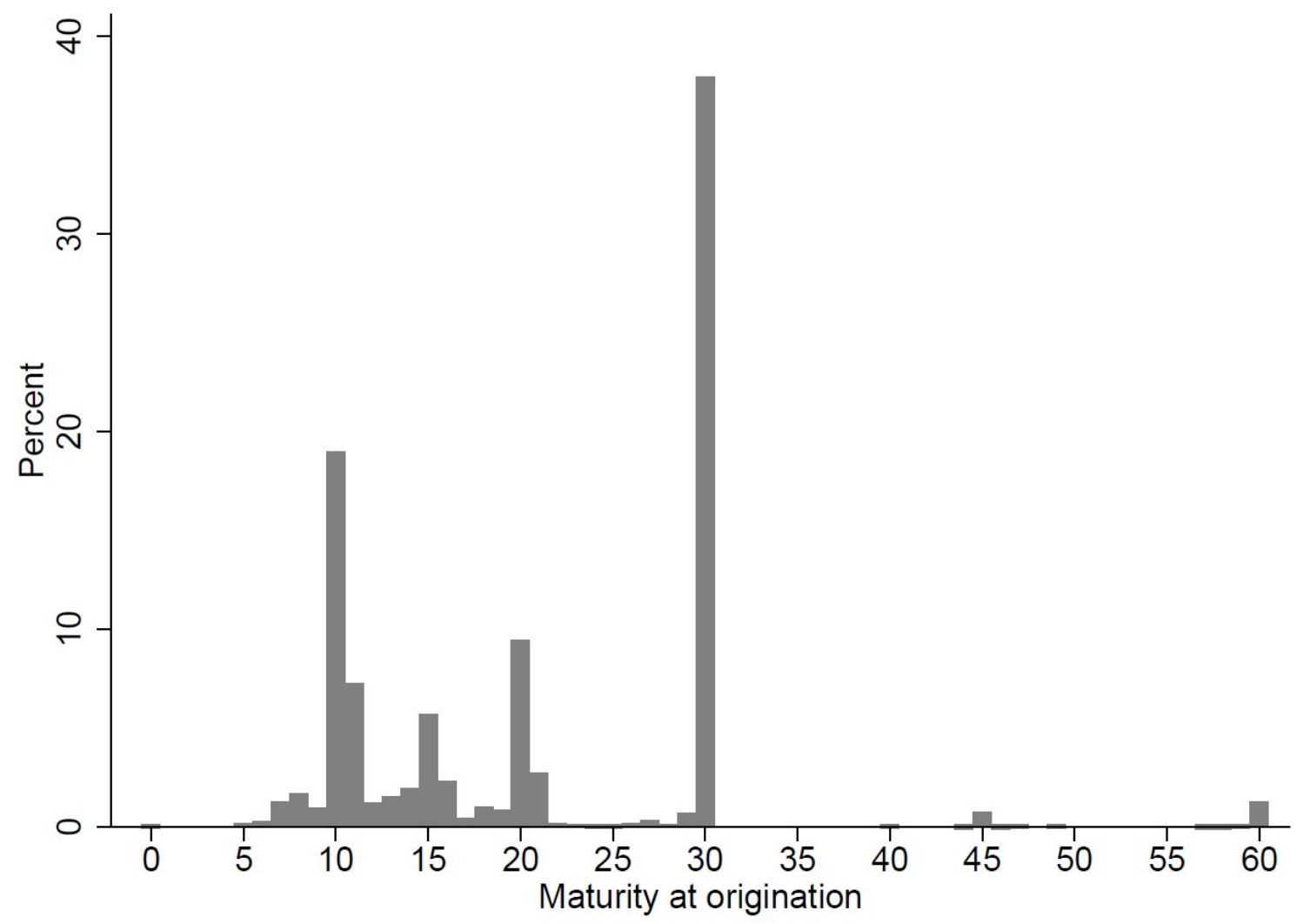

This Figure plots the distribution of mortgage maturities at origination for the subsample of active mortgages in 2009 using data mortgage contract-level data. 
Figure 3. Share of Inviduals working Part-Time

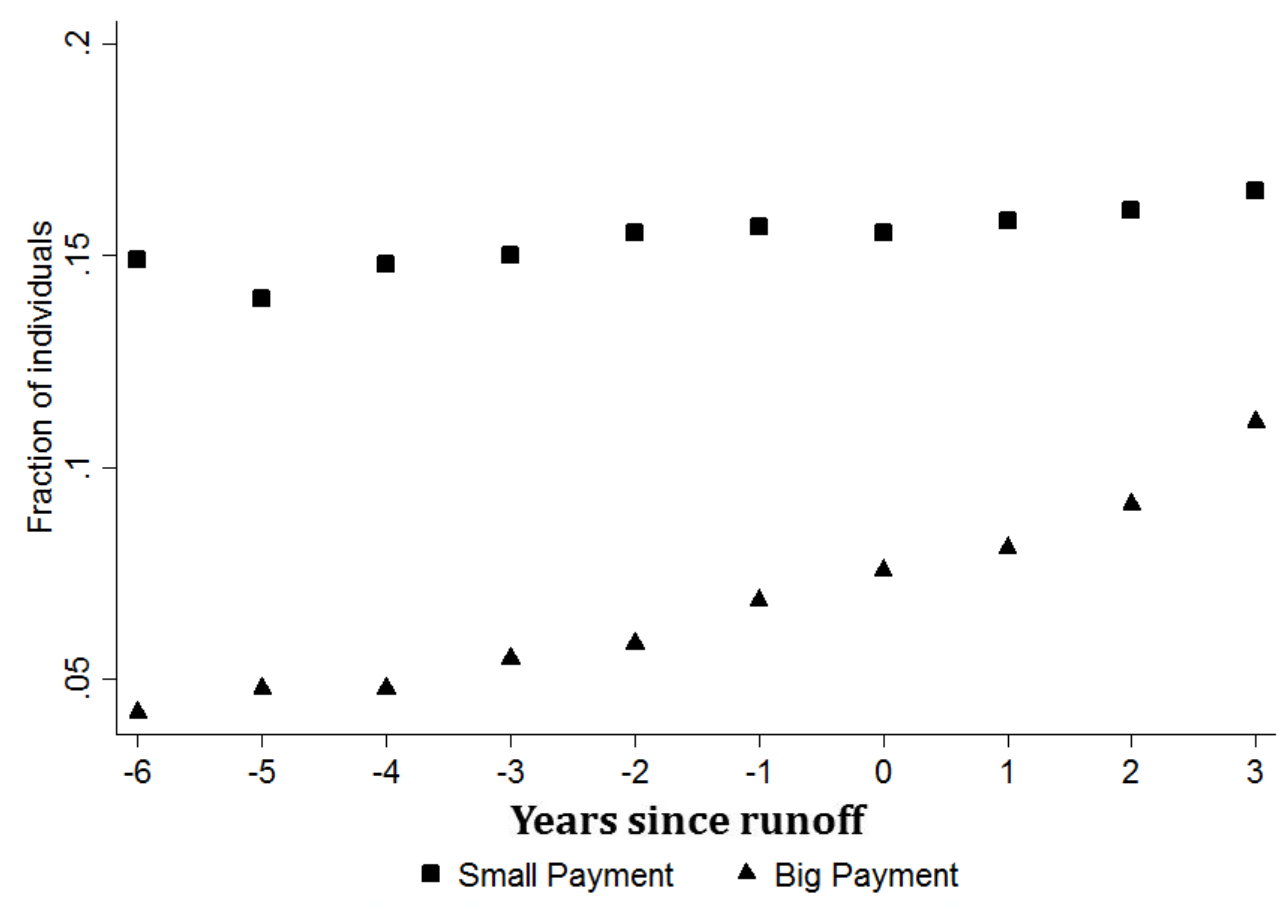

This Figure plots the share of individuals that are part-time workers for individuals with small mortgage payments (i.e. under the average value of 34,000 DKK) and big mortgage payments (i.e. above the average value of 34,000 DKK). 
Figure 4. Labor Income and Bank Loans Response

Column 1: Years since run-off dummies x $\overline{\text { Payment }}$



Column 2: Years since run-off dummies x (Payment-Payment)

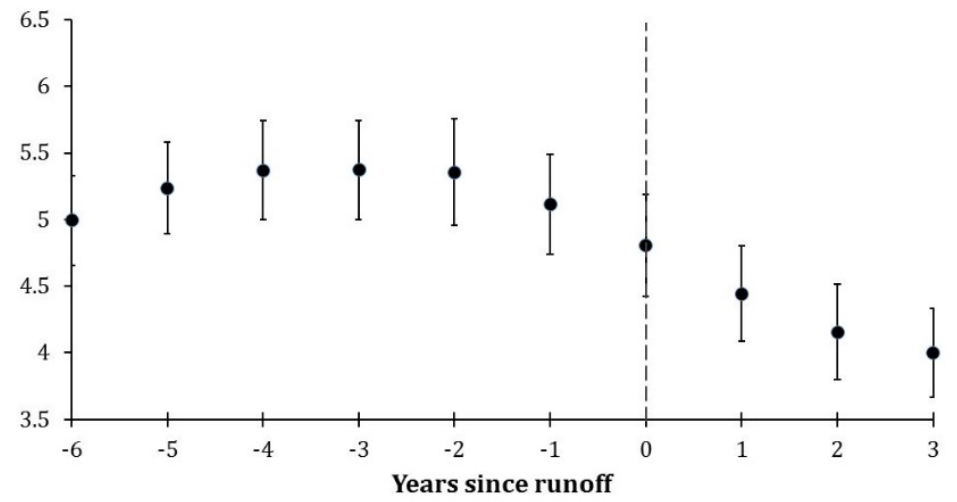

i) Labor Income

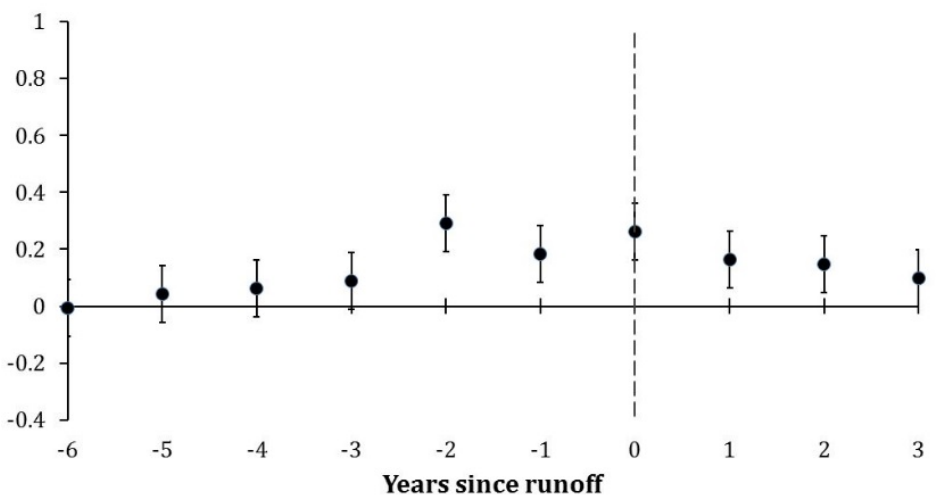

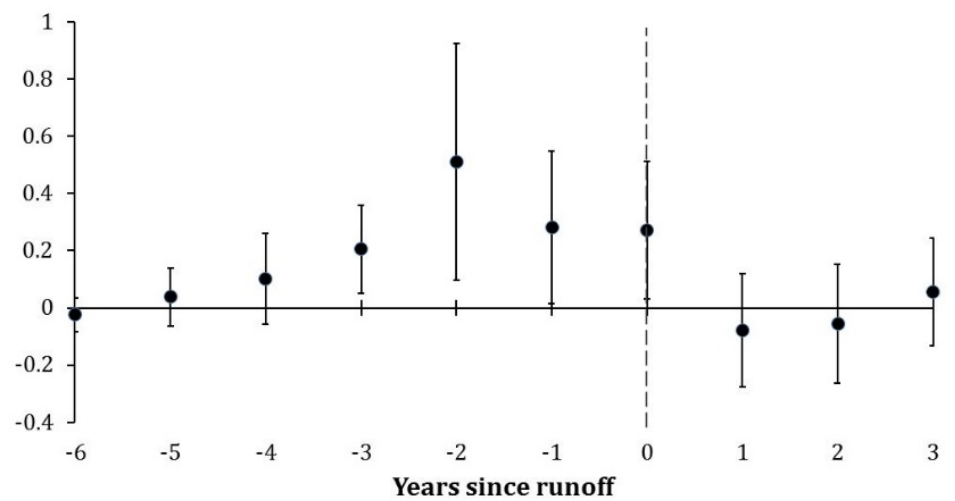

ii) $\triangle$ Bank Loans

This figure plots the results of OLS regressions on labor income and changes in bank loans. The first column shows the results from regressions including only years since run-off dummies. The black dots show the coefficients on the run-off dummies (along with their $95 \%$ confidence interval). The second column presents the results of regressions including years since run-off dummies, the mortgage payment, and their interaction. The black dots present the coefficients of years since run-off dummies multiplied by the mortgage payment plus the baseline coefficient on the mortgage payment (along with 95\% confidence intervals). 
Table 1: Run-offs Literature Comparison

\begin{tabular}{|c|c|c|c|c|c|}
\hline & Andersen et al. (2017) & d'Astous (2017) & Scholnik (2013) & Stephens (2008) & Coulibaly and $\mathrm{Li}$ (2006) \\
\hline Run-off Type & Mortgage & Term Loans & Mortgage & Car Loans & Mortgage \\
\hline Data Source & Danish registries & North American bank & Canadian bank & CEX & CEX \\
\hline Data Type & Administrative data & Administrative data & Administrative data & Survey & Survey \\
\hline \# Run-offs & 14,581 & 291,777 & 147 & Approx. 200 & 286 \\
\hline Sample Period & $1995-2014$ & Dec/2009 - May/2013 & Dec/2004 - June/2006 & $1984-2000$ & $1988-2001$ \\
\hline Identification & $\begin{array}{c}\text { Glide path with } \\
\text { imperfect and perfect } \\
\text { compliance }\end{array}$ & $\begin{array}{c}\text { Glide path with } \\
\text { imperfect and perfect } \\
\text { compliance }\end{array}$ & $\begin{array}{l}\text { Glide path with perfect } \\
\text { compliance }\end{array}$ & Changes in payments & $\begin{array}{l}\text { Glide path with } \\
\text { imperfect compliance }\end{array}$ \\
\hline $\begin{array}{l}\text { Constrained / } \\
\text { Unconstrained } \\
\text { Subsamples } \\
\end{array}$ & $\begin{array}{l}\text { Yes (Pre-existing debt / } \\
\text { assets before run-off) }\end{array}$ & $\begin{array}{l}\text { Yes (Fraction of card } \\
\text { balance paid) }\end{array}$ & $\begin{array}{l}\text { Yes (Interest payments on } \\
\text { card balances) }\end{array}$ & $\begin{array}{l}\text { Yes (Age, \% of liquid } \\
\text { wealth, loan maturity) }\end{array}$ & No \\
\hline \multicolumn{6}{|c|}{ Share of freed up resources that go to each source after the run-off (Average Effects) ${ }^{i}$} \\
\hline Leisure & Earnings decline (21\%) & - & - & - & - \\
\hline Consumption & - & $\begin{array}{l}\text { Card expenditures }(9 \%) \text {, } \\
\text { New term loans }(18 \%)^{\mathrm{ii}}\end{array}$ & Card expenditures $(17 \%)^{\mathrm{iii}}$ & $\begin{array}{l}\text { Nondurables (12\%), } \\
\text { Other (NS) }\end{array}$ & $\begin{array}{c}\text { Nondurables (NS), } \\
\text { Home furnishing (19\%), } \\
\text { Entertainment (4\%), } \\
\text { Vehicles (NS) } \\
\end{array}$ \\
\hline Savings/Assets & $\begin{array}{c}\text { Stocks (NS), } \\
\text { Bonds (NS), } \\
\text { Bank deposits (NS) }\end{array}$ & - & - & - & Savings (32\%) \\
\hline Debt reduction & $\begin{array}{l}\text { Non-mortgage loan } \\
\text { reduction (31\%) }\end{array}$ & - & - & - & - \\
\hline
\end{tabular}

i. The table shows the share of freed up resources from each run-off that go to each source after the run-off based on the coefficients provided by these authors. Results are transformed when necessary to make results comparable across studies. We report estimates with at least a $10 \%$ significance level. "NS" indicates a non-statistically significant result.

ii. Card expenditure result from column 1 of Table 4 . New term loan result calculated by multiplying the increase in the probability of getting a new loan after the run-off (0.0084, from column 2 of Table 3) times the average new loan size (\$2,198 from column 1 of Table 2), divided by average pre-run-off payment ( $\$ 102$, from Table 2).

iii. Marginal effect calculated as an average of monthly effects 0 to 6 months post-run-off for a run-off of average size (\$751, Table 1), using quadratic estimates (last column of Table

2). For example, the marginal effect for month 0 is $0.671+2 *(-0.000466) * 751$. Result included although significance of this average effect is unknown.

iv. The nondurables coefficient ( 0.281 from model 1 from Table 2 of Stephens) shows the effect of a payment change as a share of income on the percent (literally log) change in nondurables expenditure. To make this result comparable to others, we multiple it by the share of income devoted to non-durables in a CEX sample (0.4165 = $\$ 917 /(\$ 26,420 / 12)$, where $\$ 917$ is the average monthly non-durables consumption from Table 1 in Coulibaly and $\mathrm{Li}$ and $\$ 26,420$ is the average annual income from Table 7 in Coulibaly and Li). "Other” refers to consumption of food, strictly nondurables, and other consumption. 


Mean Std. Dev.

A. Demographics

\begin{tabular}{lrlr} 
Age & 56.9 & & 10.3 \\
Male & 61.2 & $\%$ & - \\
\# Adults in household & 1.9 & & 0.6 \\
Married & 72.7 & $\%$ & - \\
Divorced & 7.2 & $\%$ & - \\
Retired & 41.5 & $\%$ & - \\
Income and Pensions ('000s DKK) & & & \\
Labor Income & 222.0 & DKK & 112.7 \\
Total Pension Outflows & 48.7 & DKK & 70.3 \\
Total Pension Inflows & 20.7 & DKK & 49.1 \\
Wealth ('000s DKK) & & & \\
Bank Deposits & 91.3 & DKK & 157.2 \\
Stocks & 35.1 & DKK & 152.5 \\
Bonds & 51.5 & DKK & 346.3 \\
Bank Loans & 31.7 & DKK & 85.2 \\
Housing ('000s DKK) & & & \\
Housing Assets & $1,006.8$ & DKK & 683.8 \\
Mortgage Value & 134.1 & DKK & 73.2 \\
Mortgage Payments & 33.7 & DKK & 18.6 \\
Mortgage Payments/Income & 22.2 & $\%$ & 1.7 \\
\hline
\end{tabular}

This table provides descriptive statistics for the main variables used in the analysis. The sample used is based on the mortgage run-off as predicted three years before the mortgage is paid off. There are 15,895 run-off events. All variables are recorded at the end of the calendar year and are measured three years prior to the year in which the mortgage is paid off. Labor income and mortgage payments are annual. All monetary amounts are expressed in Danish kroner (DKK). The exchange rate between DKK and U.S. dollar was $14.94 \%$ at the beginning of our sample in 1995, averaged $16.27 \%$ over the sample and was $17.81 \%$ at the end of our sample in 2014. 
Table 3. Average Results

\begin{tabular}{|c|c|c|c|c|c|}
\hline & Labor Income & $\Delta$ Bank Deposits & $\Delta$ Stocks & $\Delta$ Bonds & $\begin{array}{c}\Delta \text { Bank } \\
\text { Loans }\end{array}$ \\
\hline After $\mathrm{x}$ & $-0.14 * * *$ & $-0.17 * *$ & -0.03 & -0.04 & -0.09 \\
\hline$\overline{\text { Payment }}$ & $(0.03)$ & $(0.09)$ & $(0.05)$ & $(0.07)$ & $(0.07)$ \\
\hline $\begin{array}{l}\text { After x } \\
\qquad \text { (Payment- } \overline{\text { Payment }})\end{array}$ & $\begin{array}{c}-0.39 * * * \\
(0.14)\end{array}$ & $\begin{array}{l}-0.12 \\
(0.34)\end{array}$ & $\begin{array}{c}0.07 \\
(0.12)\end{array}$ & $\begin{array}{l}-0.15 \\
(0.18)\end{array}$ & $\begin{array}{c}-0.53^{* *} \\
(0.24)\end{array}$ \\
\hline $\mathrm{R}^{2}$ & 0.061 & 0.001 & 0.015 & 0.002 & 0.004 \\
\hline
\end{tabular}

This table shows the results of OLS regressions which control for year fixed effects, individual fixed effects, and linear run-off year and its interaction with the size of annual mortgage payment. The sample used is based on the mortgage run-off as predicted three years before the mortgage is paid off. There are 15,895 run-off events. Dependent variables are labor income, measured as total income in thousands of Danish kroner (DKK) received during the calendar year, and bank deposits, stocks, bonds and bank loans, measured as changes in thousands of DKK from their value at the end of the previous calendar year. After is a variable equal to zero in the three years before the mortgage is paid off and one in the three years after the mortgage is paid off. Payment is the individual-level average annual mortgage payment in thousands of DKK three to six years before the mortgage is paid off, as reported in Table 2. Payment is the average value in thousands of DKK of the payment in the regression sample. Standard errors clustered at the individual level are presented in parentheses. ***, **, * represent statistical significance at the 1, 5, and 10 percent levels respectively. 


Labor Income $\quad \Delta$ Bank Deposits $\Delta$ Stocks $\Delta$ Bonds $\quad \Delta$ Bank Loans

A. No Stocks+Bonds, No Debt (No. of run-offs $=10,058)$

$\begin{array}{lccccc}\text { After x } & -0.16^{* * *} & -0.14 & -0.06^{*} & -0.07 & -0.17^{* *} \\ \quad \overline{\text { Payment }} & (0.04) & (0.10) & (0.03) & (0.07) & (0.09) \\ \text { After x } & -0.47^{* * *} & -0.19 & -0.20^{*} & 0.15 & -0.41 \\ \quad(\text { Payment-Payment) } & (0.14) & (0.40) & (0.11) & (0.19) & (0.26) \\ \mathrm{R}^{2} & 0.058 & 0.002 & 0.012 & 0.001 & 0.002\end{array}$

B. Some Stocks+Bonds or Debt (No. of run-offs $=5,837$ )

\begin{tabular}{|c|c|c|c|c|c|}
\hline After $x$ & $-0.12^{* *}$ & -0.22 & -0.01 & -0.00 & 0.02 \\
\hline$\overline{\text { Payment }}$ & $(0.05)$ & $(0.15)$ & $(0.12)$ & $(0.13)$ & $(0.12)$ \\
\hline After $x$ & -0.31 & -0.02 & 0.26 & -0.51 & $-0.76^{*}$ \\
\hline (Payment-Payment) & $(0.28)$ & $(0.58)$ & $(0.23)$ & $(0.33)$ & $(0.45)$ \\
\hline $\mathrm{R}^{2}$ & 0.066 & 0.004 & 0.004 & 0.003 & 0.007 \\
\hline
\end{tabular}

B1. No Stocks+Bonds, Yes Debt (No. of run-offs $=2,467$ )

$\begin{array}{lccccc}\text { After x } & -0.13^{*} & -0.12 & -0.02 & -0.13 & 0.13 \\ \quad \overline{\text { Payment }} & (0.07) & (0.16) & (0.03) & (0.11) & (0.20) \\ \text { After x } & 0.02 & -0.59 * & -0.10 & -0.61 & -1.31^{*} \\ \quad \text { (Payment-Payment) } & (0.16) & (0.35) & (0.11) & (0.46) & (0.77) \\ \mathrm{R}^{2} & 0.072 & 0.002 & 0.016 & 0.004 & 0.011\end{array}$

B2. Yes Stocks+Bonds, No Debt (No. of run-offs $=2,996)$

$\begin{array}{lccccc}\text { After x } & -0.06 & -0.34 & -0.02 & 0.05 & -0.22 * \\ \quad \overline{\text { Payment }} & (0.06) & (0.26) & (0.24) & (0.25) & (0.13) \\ \text { After x } & 0.10 & -0.80 & 0.76 & -0.38 & -0.89 * * \\ \quad(\text { Payment-Payment) } & (0.16) & (0.81) & (0.47) & (0.58) & (0.41) \\ \mathrm{R}^{2} & 0.05 & 0.003 & 0.11 & 0.023 & 0.004\end{array}$

B3. Yes Stocks+Bonds, Yes Debt (No. of run-offs $=374)$

$\begin{array}{lccccc}\text { After x } & -0.32 & 0.02 & 0.04 & 0.45 & 0.8 \\ \overline{\text { Payment }} & (0.22) & (0.57) & (0.51) & (0.48) & (0.56) \\ \text { After x } & -2.93^{* *} & 4.89 * * & -0.10 & -0.94 & 0.79 \\ \quad \text { (Payment-Payment) } & (1.47) & (2.28) & (0.83) & (0.67) & (1.61) \\ \mathrm{R}^{2} & 0.152 & 0.026 & 0.015 & 0.007 & 0.02\end{array}$

This table shows the results of OLS regressions which control for year fixed effects, individual fixed effects, and linear run-off year and its interaction with the size of annual mortgage payment. The sample used is based on the mortgage run-off as predicted three years before the mortgage is paid off. Dependent variables are labor income, measured as total income in thousands of Danish kroner (DKK) received during the calendar year, and bank deposits, stocks, bonds and bank loans, measured as changes in thousands of DKK from their value at the end of the previous calendar year. After is a variable equal to zero in the three years before the mortgage is paid off and one in the three years after the mortgage is paid off. Payment is the individual-level average annual mortgage payment in thousands of DKK three to six years before the mortgage is paid off, as reported in Table 2. Payment is the average value in thousands of DKK of the payment in the regression sample. It is equal to 31.84, 38.61, 34.51, and 46.57 for individuals in Panels A., B., C., and D., respectively. An individual is identified as having debt if her end-of-year debt is higher than 50,000 DKK on average six to three years before the predicted final payment. Similarly, an individual is identified as holding stocks and bonds if the value of her end-of-year stocks and bonds combined is higher than 50,000 DKK on average six to three years before the predicted final payment. Standard errors 


\begin{tabular}{|c|c|c|c|c|c|}
\hline & Labor Income & $\Delta$ Bank Deposits & $\Delta$ Stocks & $\Delta$ Bonds & $\Delta$ Bank Loans \\
\hline \multicolumn{6}{|c|}{ A. All Sample (No. of run-offs $=5,770)$} \\
\hline After $x$ & -0.04 & -0.11 & -0.05 & -0.05 & $-0.23^{* *}$ \\
\hline$\overline{\text { Payment }}$ & $(0.04)$ & $(0.12)$ & $(0.06)$ & $(0.07)$ & $(0.11)$ \\
\hline After $x$ & -0.50 & 0.17 & -0.29 & -0.14 & $-1.18^{* *}$ \\
\hline (Payment- $\overline{\text { Payment }}$ ) & $(0.33)$ & $(0.63)$ & $(0.21)$ & $(0.18)$ & $(0.48)$ \\
\hline $\mathrm{R}^{2}$ & 0.047 & 0.003 & 0.009 & 0.001 & 0.007 \\
\hline \multicolumn{6}{|c|}{ B. No Stocks+Bonds, No Debt (No. of run-offs $=3,368$ ) } \\
\hline After x & 0.01 & -0.13 & $0.13^{* *}$ & $0.09 *$ & 0.15 \\
\hline$\overline{\text { Payment }}$ & $(0.07)$ & $(0.16)$ & $(0.05)$ & $(0.05)$ & $(0.10)$ \\
\hline After $x$ & $-0.56^{*}$ & 0.26 & -0.36 & $0.17^{*}$ & -0.44 \\
\hline (Payment- $\overline{\text { Payment }}$ ) & $(0.33)$ & $(0.49)$ & $(0.27)$ & $(0.10)$ & $(0.29)$ \\
\hline $\mathrm{R}^{2}$ & 0.052 & 0.004 & 0.014 & 0.003 & 0.003 \\
\hline \multicolumn{6}{|c|}{ C. No Stocks+Bonds, Yes Debt (No. of run-offs $=1,231$ ) } \\
\hline After $x$ & -0.04 & -0.35 & 0.05 & 0.06 & $-0.91 * * *$ \\
\hline$\overline{\text { Payment }}$ & $(0.08)$ & $(0.25)$ & $(0.04)$ & $(0.06)$ & $(0.30)$ \\
\hline After $x$ & -0.07 & -0.16 & 0.01 & -0.46 & $-2.92 * *$ \\
\hline (Payment- $\overline{\text { Payment }}$ ) & $(0.20)$ & $(0.70)$ & $(0.07)$ & $(0.40)$ & $(1.30)$ \\
\hline $\mathrm{R}^{2}$ & 0.055 & 0.003 & 0.022 & 0.005 & 0.025 \\
\hline \multicolumn{6}{|c|}{ D. Yes Stocks+Bonds, No Debt (No. of run-offs $=956)$} \\
\hline After x & 0.02 & 0.46 & -0.42 & $-0.66^{*}$ & 0.22 \\
\hline$\overline{\text { Payment }}$ & $(0.12)$ & $(0.42)$ & $(0.32)$ & $(0.38)$ & $(0.28)$ \\
\hline After $x$ & 0.42 & -0.69 & 0.07 & -0.09 & -0.05 \\
\hline (Payment- $\overline{\text { Payment }}$ ) & $(0.29)$ & $(0.65)$ & $(0.73)$ & $(0.71)$ & $(0.35)$ \\
\hline $\mathrm{R}^{2}$ & 0.035 & 0.01 & 0.138 & 0.013 & 0.006 \\
\hline \multicolumn{6}{|c|}{ E. Yes Stocks+Bonds, Yes Debt $($ No. of run-offs $=215)$} \\
\hline After $\mathrm{x}$ & 0.09 & $-1.43^{*}$ & -0.16 & -0.07 & -0.86 \\
\hline$\overline{\text { Payment }}$ & $(0.26)$ & $(0.82)$ & $(0.84)$ & $(0.86)$ & $(0.94)$ \\
\hline After $x$ & -2.77 & 2.42 & -1.17 & -0.06 & -1.71 \\
\hline (Payment- $\overline{\text { Payment }}$ ) & $(1.73)$ & $(4.14)$ & $(1.02)$ & $(0.65)$ & $(2.86)$ \\
\hline $\mathrm{R}^{2}$ & 0.148 & 0.035 & 0.016 & 0.01 & 0.036 \\
\hline
\end{tabular}

This table shows the results of OLS regressions which control for year fixed effects, individual fixed effects, and linear run-off year and its interaction with the size of annual mortgage payment. The sample used is based on the mortgage run-off as predicted three years before the mortgage is paid off, with the additional restriction that we drop individuals who are retired at any point of the sample. Dependent variables are labor income, measured as total income in thousands of DKK received during the calendar year, and bank deposits, stocks, bonds and bank loans, measured as changes in thousands of DKK with respect to their value at the end of the previous calendar year. An individual is identified as having debt if her end-of-year debt is higher than 50,000 DKK on average in the six years before the predicted final payment. Similarly, we say an individual is identified as holding stocks and bonds if the value of her end-of-year stocks and bonds combined is higher than 50,000 DKK on average in the six years before the predicted final payment. After is a variable equal to zero in the three years before the mortgage is paid off and one in the three years after the mortgage is paid off. Payment is the individual-level average annual mortgage payment in thousands of DKK three to six years before the mortgage is paid off, as reported in Table 2. Payment is the average value in thousands of DKK of the payment in the regression sample. Standard errors clustered at the individual level are presented in parentheses. ***, **, * represent statistical significance at the 1,5 , and 10 percent levels respectively. 
Table A2. Pension, Retirement, and Unemployment

\begin{tabular}{lcccc}
\hline & \multicolumn{2}{c}{ Pension } & & \\
\cline { 2 - 3 } & Outflows & Inflows & Retirement & Unemployment \\
\hline After x & 0.028 & -0.091 & 0.28 & 0.11 \\
$\overline{\text { Payment }}$ & $(0.034)$ & $(0.078)$ & $(0.19)$ & $(0.28)$ \\
& & & & \\
After x & $0.055^{* * *}$ & $-0.047^{* *}$ & & \\
$\quad($ Payment-Payment) & $(0.014)$ & $(0.020)$ & & \\
& & & & -1.44 \\
After x & & & 0.31 & $(0.95)$ \\
$\quad$ Payment-Payment)/100,000 & & & $(0.46)$ & \\
$\quad \mathrm{R}^{2}$ & & & & 0.016 \\
No. of Run-offs & 0.18 & 0.0086 & 0.014 & 10,324 \\
\hline
\end{tabular}

This table shows OLS regressions on pension outflows and inflows, as well marginal effects derived from logit regressions on the probability of retiring and becoming unemployed. All regressions control for year fixed effects, and linear run-off year and its interaction with the size of annual mortgage payment. OLS regressions further include individual fixed effects. Pension outflows and inflows are the sum of employer and private pensions measured in thousands of Danish kroner (DKK) at the end of the year. Retirement and unemployment are defined as going from unretired to retired, and employed to unemployed in a given year, respectively. Being employed is defined as receiving a salary during the calendar year, alternatively, being out of the labor force is defined as any form of unemployment (including being on leave for maternity or medical reasons, being a student, being retired or being on poverty cash benefits). The sample used is based on the mortgage run-off as predicted three years before the mortgage is paid off. After is a variable equal to zero in the three years before the mortgage is paid off and one in the three years after the mortgage is paid off. Payment is the individual-level average annual mortgage payment in thousands of DKK three to six years before the mortgage is paid off, as reported in Table 2. $\overline{\text { Payment }}$ is the average value in thousands of DKK of the payment in the regression sample. Standard errors clustered at the individual level are presented in parentheses. ${ }^{* * *}, * *, *$ represent statistical significance at the 1,5 , and 10 percent levels respectively. 


\begin{tabular}{|c|c|c|c|c|c|}
\hline & All & $\begin{array}{c}\text { No } \\
\text { Stock+Bond, } \\
\text { No Debt }\end{array}$ & $\begin{array}{c}\text { No } \\
\text { Stock+Bond, } \\
\text { Yes Debt }\end{array}$ & $\begin{array}{c}\text { Yes } \\
\text { Stock+Bond, } \\
\text { No Debt }\end{array}$ & $\begin{array}{c}\text { Yes } \\
\text { Stock+Bond, } \\
\text { Yes Debt }\end{array}$ \\
\hline \multicolumn{6}{|l|}{ A. Extensive Margin } \\
\hline After $x$ & $-2.40 * * *$ & $-1.85 * *$ & $-3.11 * * *$ & $-3.38 * *$ & -0.91 \\
\hline$\overline{\text { Payment }}$ & $(0.53)$ & $(0.79)$ & $(0.93)$ & $(1.40)$ & $(1.87)$ \\
\hline After $x$ & -0.61 & -0.05 & -1.20 & -0.03 & -0.23 \\
\hline 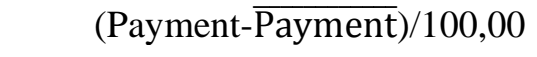 & $(0.44)$ & $(0.73)$ & $(0.79)$ & $(1.26)$ & $(1.32)$ \\
\hline $\mathrm{R}^{2}$ & 0.0445 & 0.0486 & 0.0339 & 0.0539 & 0.0381 \\
\hline \multicolumn{6}{|l|}{ B. Intensive Margin } \\
\hline After $x$ & $-17.50 * *$ & -1.57 & $-46.53 * * *$ & $-69.98 * * *$ & 3.39 \\
\hline$\overline{\text { Payment }}$ & $(7.71)$ & $(12.20)$ & (13.47) & (19.19) & $(12.41)$ \\
\hline After $\mathrm{x}$ & $20.07 *$ & 0.95 & $45.74 * *$ & $289.84 * * *$ & 8.81 \\
\hline (Payment-Payment $)$ & (12.07) & $(8.45)$ & (20.89) & $(18.35)$ & $(15.11)$ \\
\hline $\mathrm{R}^{2}$ & 0.2087 & 0.5304 & 0.6735 & 0.8141 & 0.6066 \\
\hline No. of Observations & 934 & 489 & 262 & 140 & 43 \\
\hline
\end{tabular}

This table shows the extensive and intensive margins of new mortgage takeout. We call an annual increase in mortgage balance greater than 500,000 DKK a new mortgage. Panel A. shows the coefficients of logit regressions on a binary variable equal to one if the individual has a new mortgage in a calendar year and zero otherwise. All regressions control for year fixed effects, and linear run-off year and its interaction with the size of annual mortgage payment. OLS regressions further include individual fixed effects. The sample used is based on the mortgage run-off as predicted three years before the mortgage is paid off. After is a variable equal to zero in the three years before the mortgage is paid off and one in the three years after the mortgage is paid off. Payment is the individual-level average annual mortgage payment three to six years before the mortgage is paid off (expressed in millions of DKK in Panel B). Payment is the average value of the payment in the regression sample (expressed in millions of DKK in Panel B). An individual is identified as having debt if her end-of-year debt is higher than 50,000 DKK on average six to three years before the predicted final payment. Similarly, an individual is identified as holding stocks and bonds if the value of her end-of-year stocks and bonds combined is higher than 50,000 DKK on average six to three years before the predicted final payment. Standard errors clustered at the individual level are presented in parentheses. ${ }^{* *}, * *, *$ represent statistical significance at the 1,5 , and 10 percent levels respectively. 


\begin{tabular}{|c|c|c|c|c|c|}
\hline & Labor Income & $\Delta$ Bank Deposits & $\Delta$ Stocks & $\Delta$ Bonds & $\Delta$ Bank Loans \\
\hline \multicolumn{6}{|c|}{ A. Compliance at T0-3 (No. of run-offs $=15,895)$} \\
\hline After $x$ & $-0.14 * * *$ & $-0.17 * *$ & -0.03 & -0.04 & -0.09 \\
\hline$\overline{\text { Payment }}$ & $(0.03)$ & $(0.09)$ & $(0.05)$ & $(0.07)$ & $(0.07)$ \\
\hline After $x$ & $-0.39 * * *$ & -0.12 & 0.07 & -0.15 & $-0.53 * *$ \\
\hline (Payment-Payment $)$ & $(0.14)$ & $(0.34)$ & $(0.12)$ & $(0.18)$ & $(0.24)$ \\
\hline $\mathrm{R}^{2}$ & 0.061 & 0.001 & 0.015 & 0.002 & 0.004 \\
\hline \multicolumn{6}{|c|}{ B. Compliance at T0-3 and T0-2 (No. of run-offs = 14,389) } \\
\hline After $x$ & $-0.16^{* * *}$ & $-0.20 * *$ & -0.01 & 0.02 & $-0.15^{* *}$ \\
\hline$\overline{\text { Payment }}$ & $(0.03)$ & $(0.09)$ & $(0.06)$ & $(0.07)$ & $(0.06)$ \\
\hline After $\mathrm{x}$ & $-0.42 * * *$ & 0.01 & 0.11 & 0.00 & $-0.44 *$ \\
\hline (Payment- $\overline{\text { Payment }}$ ) & $(0.16)$ & $(0.33)$ & $(0.13)$ & $(0.18)$ & $(0.24)$ \\
\hline $\mathrm{R}^{2}$ & 0.066 & 0.001 & 0.015 & 0.003 & 0.004 \\
\hline \multicolumn{6}{|c|}{ C. Compliance at T0-3, T0-2, and T0-1 (No. of run-offs $=12,145)$} \\
\hline After x & $-0.20 * * *$ & 0.08 & 0.03 & 0.10 & $-0.23 * * *$ \\
\hline$\overline{\text { Payment }}$ & $(0.03)$ & $(0.09)$ & $(0.06)$ & $(0.07)$ & $(0.06)$ \\
\hline After $\mathrm{x}$ & $-0.47 * *$ & 0.22 & 0.15 & -0.02 & $-0.39 *$ \\
\hline (Payment- $\overline{\text { Payment }}$ ) & $(0.18)$ & $(0.32)$ & $(0.14)$ & $(0.19)$ & $(0.21)$ \\
\hline $\mathrm{R}^{2}$ & 0.07 & 0.002 & 0.032 & 0.004 & 0.003 \\
\hline \multicolumn{6}{|c|}{ D. Compliance at T0-3, T0-2, T0-1, and T0 (No. of run-offs $=6,804)$} \\
\hline After $x$ & $-0.27 * * *$ & -0.02 & 0.03 & 0.13 & $-0.38 * * *$ \\
\hline$\overline{\text { Payment }}$ & $(0.04)$ & $(0.14)$ & $(0.10)$ & $(0.11)$ & $(0.08)$ \\
\hline After $x$ & $-0.39 * * *$ & 0.21 & $0.48 * *$ & -0.30 & $-0.59 * *$ \\
\hline (Payment- $\overline{\text { Payment }}$ ) & $(0.11)$ & $(0.33)$ & $(0.23)$ & $(0.31)$ & $(0.27)$ \\
\hline $\mathrm{R}^{2}$ & 0.081 & 0.002 & 0.034 & 0.005 & 0.004 \\
\hline
\end{tabular}

This table shows the results of OLS regressions which control for year fixed effects, individual fixed effects, and linear run-off year and its interaction with the size of annual mortgage payment. The samples used vary by definition of compliance with the predicted mortgage run-off. The sample used in Panel A. is based on the mortgage run-off as predicted three years before the mortgage is paid off and the results are identical to the results presented in Table 2. The sample used in Panel B. adds the restriction that the mortgage balance is decreasing two years prior to the year in which the mortgage is paid off. The sample used in Panel C. further adds the restriction that the mortgage balance is decreasing one year prior to the year in which the mortgage is paid off. Finally, the sample used in Panel D. adds the restriction that the value of the mortgage is zero in the year in which it is predicted to be paid off. Dependent variables are labor income, measured as total income in thousands of Danish kroner (DKK) received during the calendar year, and bank deposits, stocks, bonds and bank loans, measured as changes in thousands of DKK from their value at the end of the previous calendar year. After is a variable equal to zero in the three years before the mortgage is paid off and one in the three years after the mortgage is paid off. Payment is the individual-level average annual mortgage payment in thousands of DKK three to six years before the mortgage is paid off, as reported in Table 2. $\overline{\text { Payment }}$ is the average value in thousands of DKK of the payment in the regression sample. Standard errors clustered at the individual level are presented in parentheses. $* * *, * *, *$ represent statistical significance at the 1,5 , and 10 percent levels respectively. 
(1)

A. Labor Income

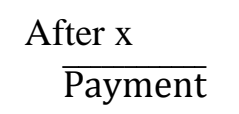

After $\mathrm{x}$

$$
\text { (Payment- } \overline{\text { Payment }} \text { ) }
$$

$\mathrm{R}^{2}$

B. $\Delta$ Bank Loans

\begin{tabular}{lccccc} 
After x & -0.09 & -0.08 & -0.08 & -0.09 & -0.09 \\
$\quad$ Payment & $(0.07)$ & $(0.07)$ & $(0.07)$ & $(0.07)$ & $(0.07)$ \\
After x & $-0.53^{* *}$ & $-0.57^{* *}$ & $-0.57^{* *}$ & $-0.26^{* *}$ & $-0.26^{* *}$ \\
$\quad($ Payment-Payment) & $(0.24)$ & $(0.25)$ & $(0.25)$ & $(0.10)$ & $(0.10)$ \\
$\mathrm{R}^{2}$ & 0.0036 & 0.0009 & 0.0014 & 0.0035 & 0.0035 \\
& & & & & \\
Year F.E. & YES & NO & NO & YES & YES \\
Person F.E. & YES & YES & NO & YES & YES \\
Event-Time & YES & YES & YES & YES & NO \\
Event-Time x Payment & YES & YES & YES & NO & NO \\
\hline
\end{tabular}

This table shows the results of OLS regressions which control for year fixed effects, individual fixed effects, and linear run-off year and its interaction with the size of annual mortgage payment. Specification (1) reproduces the baseline results of Table 2. The sample used is based on the mortgage run-off as predicted three years before the mortgage is paid off. Dependent variables are labor income, measured as total income in thousands of DKK received during the calendar year, and bank deposits, stocks, bonds and bank loans, measured as changes in thousands of DKK with respect to their value at the end of the previous calendar year. After is a variable equal to zero in the three years before the mortgage is paid off and one in the three years after the mortgage is paid off. Payment is the individual-level average annual mortgage payment in thousands of DKK three to six years before the mortgage is paid off, as reported in Table 2. $\overline{\text { Payment }}$ is the average value in thousands of DKK of the payment in the regression sample. Standard errors clustered at the individual level are presented in parentheses. ${ }^{* * *}, * *, *$ represent statistical significance at the 1,5 , and 10 percent levels respectively. 
Table A6. Household-level analysis

Labor Income $\quad \Delta$ Bank Deposits $\quad \Delta$ Stocks $\Delta$ Bonds $\Delta$ Bank Loans

A. Household-Level (Including Non-Run-off Spouses) (No. of run-offs $=12,101$ )

$\begin{array}{lccccc}\text { After x } & -0.13^{* *} & -0.25^{*} & -0.03 & -0.07 & -0.24 * \\ \quad \overline{\text { Payment }} & (0.06) & (0.13) & (0.08) & (0.09) & (0.12) \\ \text { After x } & -0.35 & 0.14 & -0.09 & -0.45 & -0.29 \\ \quad(\text { Payment-Payment) } & (0.24) & (0.43) & (0.21) & (0.28) & (0.39) \\ \mathrm{R}^{2} & 0.067 & 0.002 & 0.04 & 0.005 & 0.002\end{array}$

B. Household-Level (Excluding Non-Run-off Spouses) (No. of run-offs $=12,973$ )

$\begin{array}{lccccc}\text { After x } & -0.16^{* * *} & -0.21^{* *} & -0.04 & -0.03 & -0.09 \\ \quad \overline{\text { Payment }} & (0.03) & (0.09) & (0.06) & (0.07) & (0.07) \\ \text { After x } & -0.43^{* * *} & -0.03 & -0.01 & -0.11 & -0.43^{* *} \\ \quad \text { (Payment-Payment) } & (0.17) & (0.33) & (0.15) & (0.19) & (0.22) \\ \mathrm{R}^{2} & 0.074 & 0.001 & 0.033 & 0.004 & 0.004\end{array}$

C. Non-Run-off Spouses (No. of run-offs $=7,396$ )

$\begin{array}{cccccc}\text { After x } & 0.03 & -0.12 & -0.04 & -0.13 & -0.13 \\ \overline{\text { Payment }} & (0.08) & (0.14) & (0.07) & (0.08) & (0.15) \\ \text { After x } & 0.08 & 0.00 & -0.20 & -0.58^{*} & 0.08 \\ \quad \text { (Payment-Payment) } & (0.26) & (0.59) & (0.25) & (0.31) & (0.56) \\ \mathrm{R}^{2} & 0.027 & 0.001 & 0.017 & 0.002 & 0.001\end{array}$

This table shows the results of OLS regressions which control for year fixed effects, individual fixed effects, and linear run-off year and its interaction with the size of annual mortgage payment. The samples used vary by definition of households. The sample used in Panel A. sums all outcomes at the level of the household, even when one of the spouse does not have a run-off recorded in the data. The sample used in Panel B. sums all outcomes at the level of the household, but omits spouses for which no run-off is recorded in the data. The sample used in Panel C. only keeps the spouses that do not have a run-off within a run-off-household. Dependent variables are labor income, measured as total income in thousands of DKK received during the calendar year, and bank deposits, stocks, bonds and bank loans, measured as changes in thousands of DKK with respect to their value at the end of the previous calendar year. After is a variable equal to zero in the three years before the mortgage is paid off and one in the three years after the mortgage is paid off. Payment is the individual-level average annual mortgage payment in thousands of DKK three to six years before the mortgage is paid off, as reported in Table 2. Payment is the average value in thousands of DKK of the payment in the regression sample. Standard errors clustered at the individual level are presented in parentheses. ***, **, * represent statistical significance at the 1 , 5 , and 10 percent levels respectively. 
Table A7. Placebo (Small mortgage payments)

\begin{tabular}{lccccc}
\hline & Labor Income & $\Delta$ Bank Deposits & $\Delta$ Stocks & $\Delta$ Bonds & $\Delta$ Bank Loans \\
\hline \multicolumn{2}{l}{ All Sample (No. of run-offs $=60,114)$} & & & & \\
After & $-1.87^{* *}$ & 0.78 & 0.83 & -0.08 & $-2.16^{* *}$ \\
\multirow{2}{*}{ After x High Pmts } & $(0.77)$ & $(1.54)$ & $(0.89)$ & $(1.13)$ & $(0.99)$ \\
& $-2.78^{* *}$ & $-6.72^{* *}$ & -2.91 & -1.45 & -0.96 \\
$\mathrm{R}^{2}$ & $(1.21)$ & $(3.25)$ & $(2.00)$ & $(2.47)$ & $(2.50)$ \\
\hline
\end{tabular}

This table shows the results of OLS regressions which control for year fixed effects, individual fixed effects, and linear run-off year and its interaction with the size of annual mortgage payment as well as with a binary variable indicating whether the individual's mortgage payment is higher than $10 \%$ of her labor income. The sample used is based on the mortgage run-off as predicted three years before the mortgage is paid off, without imposing the restriction that the mortgage payment be higher than $10 \%$ of the individual's labor income. Dependent variables are labor income, measured as total income in thousands of DKK received during the calendar year, and bank deposits, stocks, bonds and bank loans, measured as changes in thousands of DKK with respect to their value at the end of the previous calendar year. After is a variable equal to zero in the three years before the mortgage is paid off and one in the three years after the mortgage is paid off. High Pmts is a variable equal to one if the mortgage payments are higher than $10 \%$ of labor income, and zero otherwise. Standard errors clustered at the individual level are presented in parentheses. ${ }^{* * *},{ }^{* *},{ }^{*}$ represent statistical significance at the 1,5 , and 10 percent levels respectively. 